\title{
Analysis of Protein Amino Acids in Tobacco Using Microwave Digestion of Plant Material*
}

\author{
by \\ Serban C. Moldoveanu \\ R.J. Reynolds Tobacco Co., Winston-Salem, NC 27105, USA
}

\section{SUMMARY}

This paper describes a technique using microwave digestion and gas chromatography-mass spectrometry (GCMS), which makes possible the analysis of protein amino acids in tobacco. The technique involves first the measurement of free amino acids, a hydrolysis using microwave digestion, and a measurement of total resulting amino acids. The content of protein amino acids is determined from the difference of total and free amino acids. The digestion is performed with aqueous $6 \mathrm{~N} \mathrm{HCl}$ (with $1 \%$ phenol) for two hours in a microwave at $120{ }^{\circ} \mathrm{C}$ in sealed vials. The GC-MS analysis is performed after the amino acids are derivatized with $N$-methyl- $N$-( $t$-butyldimethylsilyl)trifluoroacetamide (MTBSTFA). The technique provides reliable results with less than $10 \%$ relative standard deviation (RSD) for most amino acids. Only the determination of very low level amino acids is affected by larger errors. The method provides results for free amino acids that are in very good agreement with those obtained by high performance liquid chromatography (HPLC), and also results for protein levels in tobacco in agreement with data previously reported in the literature. Results are given for several single grade tobaccos and for tobacco blends from four Kentucky reference cigarettes. [Beitr. Tabakforsch. Int. 21 (2005) 451-465]

\section{ZUSAMMENFASSUNG}

Es wird ein Verfahren beschrieben, bei dem es durch das Mikrowellenaufschlußsystem und GaschromatographieMassenspektrometrie (GC-MS) möglich wird, Aminosäuren von Proteinen im Tabak zu analysieren. Das Verfahren besteht aus der Bestimmung der freien Aminosäuren, einer Hydrolyse mit dem Mikowellenaufschlußsystem und der anschließenden Bestimmung aller weiteren
Aminosäuren. Der Gehalt an Aminosäuren von Proteinen wird aus der Differenz zwischen den gesamten und den freien Aminosäuren berechnet. Der Aufschluss erfolgt mit wässriger $6 \mathrm{~N}$ HCL-Lösung (mit 1\% Phenol) in einer Mikrowelle in einem zweistündigen Verfahren in fest verschlossenen Glasflaschen. Die GC-MS Analyse erfolgt nach der Derivatisierung mit $N$-Methyl- $N$ - $(t$-butyldimethylsilyl)trifluoroacetamid (MTBSTFA). Das Verfahren liefert für die meisten Aminosäuren verlässliche Ergebnisse mit einer relativen Standardabweichung (RSD) von weniger als $10 \%$. Lediglich die Bestimmung von in geringen Mengen vorkommenden Aminosäuren ist größeren Fehlern unterworfen. Die mit dieser Methode erhaltenen Ergebnisse für freie Aminosäuren sind in sehr guter Übereinstimmung mit den Ergebnissen, die mittels HPLC erzielt wurden, und auch die Daten bezüglich der Proteinmengen im Tabak sind in Übereinstimmung mit der Literatur. Die Ergebnisse beziehen sich auf mehrere Tabake eines Grades und auf Tabakmischungen von vier Kentucky Referenzzigaretten. [Beitr. Tabakforsch. Int. 21 (2005) 451-465]

\section{RESUME}

Ce travail décrit une technique de digestion par microondes et chromatographie gazeuse-spectrométrie de masse (GC-MS), permettant d'analyser des acides aminés protéiques dans le tabac. Cette technique comprend la mesure des acides aminés libres, une hydrolyse par digestion par micro-ondes, et la mesure des acides aminés totaux. La teneur en acides aminés protéiques est déterminée par rapport à la différence entre les acides aminés totaux et libres. La digestion est conduite avec du HCL $6 \mathrm{~N}$ (avec 1\% de phénol) aqueux pendant deux heures dans un four à micro-ondes à $120^{\circ} \mathrm{C}$ dans des flacons obturés. L'analyse GC-MS a été conduite après dérivation avec $N$-méthyl- $N$-(t-butyldimethylsilyl)trifluoroacetamide 


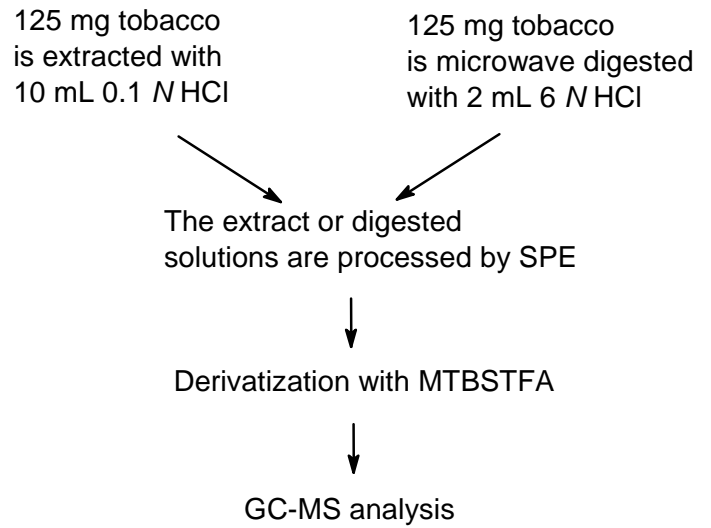

Figure 1. Main steps in the analysis of protein amino acids

(MTBSTFA). La technique fournit des résultats fiables avec un écart type relatif (RSD) de moins de $10 \%$ pour la plupart des acides aminés. La détermination des acides aminés à faibles teneurs est affectée par des erreurs plus importantes. Les résultats obtenus par la méthode pour des acides aminés libres sont en bon accord avec ceux obtenus par chromatographie en phase liquide à haute pression (HPLC), et les résultats obtenus pour les teneurs en protéines dans le tabac sont également en accord avec les données rapportés dans la littérature. Les données présentées se réfèrent à plusieurs tabacs de grades uniques et aux mélanges de tabac de quatre cigarettes de référence Kentucky. [Beitr. Tabakforsch. Int. 21 (2005) 451-465]

\section{INTRODUCTION}

Amino acids and proteins from tobacco play an important role in cigarette sensory properties (1). Although closely related from chemical point of view, certain differences exist between these two classes of compounds. For example, part of the contribution of amino acids to the sensory properties of cigarettes results from the amino acid reactions with sugars. Proteins compared to amino acids have a different propensity in reacting with other tobacco constituents such as sugars. Another important contribution to the cigarette sensory properties of free amino acids and of proteins is through their pyrolysis. Pyrolysis of single amino acids and of proteins shows many similarities but also some differences depending on the amino acid content of the protein.

Because the typical range of protein content in cured tobacco is $2-3 \%$ while that of free amino acids is about half of this amount, it is very likely that protein amino acids play a more important role in some aspects of smoke chemistry than free amino acids. This is a key reason for the need of a reliable method for the analysis of protein amino acids in tobacco.

A considerable number of analytical methods are available for the analysis of amino acids $(2,3)$. These analyses may involve either gas chromatography (GC) or liquid chromatography (LC) separations, and a variety of detection procedures such as mass spectroscopy (MS), or nitrogenphosphorus detection (NPD) coupled with GC, or ultraviolet (UV) absorption, fluorescence, MS coupled with LC, etc. Some analytical techniques measure the amino acids without any chemical modification, but most use derivatization. Many derivatization reagents are available for amino acid analysis and are reported in the literature (2). Some amino acid analytical techniques are reported for plant materials (including tobacco) and are suitable for the determination of either free amino acids (4-9) or total amino acids (10). The most common analytical techniques applied for amino acid determination are based on high performance liquid chromatography (HPLC) analysis after derivatization with $o$-phenyldialdehyde (OPA), see e.g. (11), with 6-aminoquinolyl- $N$-hydrazosuccinimidyl carbamate (ACQ) (12), or with phenylisothiocyanate (PITC), see e.g. (13). LC-MS detection is also reported for derivatized amino acids with PITC (14). GC analysis, typically followed by MS detection, is also common in amino acid analysis. Among the most frequently used techniques are the derivatization with pentafluoropropionic anhydride (PFPA) and isopropanol + acetyl chloride, see e.g. (2), derivatization with $N$-methyl- $N$-( $t$-butyldimethylsilyl)trifluoroacetamide (MTBSTFA) (15), and the more recent technique indicated as EZ:Faast ${ }^{\mathrm{TM}}$ which is suitable for both GC or LC separation (16). Other methods for GC-MS analysis such as the reaction with isobutylchloroformate at the $-\mathrm{NH}_{2}$ group and with $\mathrm{CH}_{2} \mathrm{~N}_{2}$ at the $-\mathrm{COOH}$ group $(17,18)$, or those using the reaction with methanol $+\mathrm{SOCl}_{2}$ at the - $\mathrm{COOH}$ group and with pivaldehyde (2,2-dimethylpropanal) at the $-\mathrm{NH}_{2}$ group (19) are also described in the literature for GC analysis of amino acids. The selection of an appropriate analytical method for the analysis of free and total amino acids after hydrolysis is further discussed in this study.

Hydrolysis of proteins for the analysis of their amino acid components is also a very common technique (2). A large number of studies regarding this subject have been reported (21-25), etc. Among the procedures for hydrolysis of the peptide bonds in proteins is microwave irradiation (26). Because this procedure involves a shorter hydrolysis time compared to classical hydrolysis procedures it was adopted for the analysis of tobacco proteins. The description of the modifications and optimization of microwave digestion of tobacco proteins is further discussed in this study.

\section{EXPERIMENTAL}

The experimental procedure for this analysis consists of several steps. For the determination of free amino acids, the tobacco is first extracted with $0.1 \mathrm{~N} \mathrm{HCl}$. For the determination of total amino acids the tobacco is subjected to microwave digestion. Both the tobacco extract for free amino acid determination and the microwave digested tobacco are further subjected to a cleanup/concentration step using solid phase extraction (SPE). The final solution from the SPE step is evaporated to dryness and derivatized with MTBSTFA. Finally, the derivatized material is analyzed by GC-MS and the data are processed for quantitative analysis. The main steps of the analysis are shown in Figure 1. The steps shown in Figure 1 are described in further detail. 
Table 1. Conditions for sample cleanup on the rapid trace automatic SPE system

\begin{tabular}{lllccc}
\hline Step & Source & Output & $\begin{array}{c}\text { Volume } \\
(\mathrm{mL})\end{array}$ & $\begin{array}{c}\text { Rate } \\
(\mathrm{mL} / \mathrm{min})\end{array}$ \\
\hline Purge canula & $0.1 \mathrm{~N} \mathrm{HCl}$ & Canula & 5.0 & 10 \\
Condition & $0.1 \mathrm{~N} \mathrm{HCl}$ & Waste 1 & 2.5 & 10 \\
Load & Sample & Waste 1 & 4.0 & 2 \\
Purge canula & $0.1 \mathrm{~N} \mathrm{HCl}$ & Canula & 2.0 & 20 \\
Purge canula & Water & Canula & 1.0 & 20 \\
Rinse & Water & Waste 1 & 6.0 & 10 \\
Rinse & Water & Waste 1 & 6.0 & 10 \\
Rinse & Water & Waste 1 & 6.0 & 10 \\
Rinse & Vent & Waste 3 & 0.1 & 30 \\
Dry & Nitrogen & & & \\
& $(2 \mathrm{~min})$ & & & \\
Collect & $1 \mathrm{~N} \mathrm{NH} \mathrm{HH}_{4} \mathrm{OH}$ & Fract. 1 & 5.0 & 2 \\
Collect & $1 \mathrm{~N} \mathrm{NH}_{4} \mathrm{OH}$ & Fract. 2 & 5.0 & 2 \\
Collect & $1 \mathrm{~N} \mathrm{NH}_{4} \mathrm{OH}$ & Fract. 3 & 5.0 & 2 \\
Purge canula & $\mathrm{Water}$ Waste 1 & 5.0 & 20 \\
\hline
\end{tabular}

\section{Extraction for free amino acid analysis}

Various procedures are described in the literature for the extraction of amino acids from plant material (5). Good results are obtained for tobacco using the following procedure. A representative portion of the tobacco to be analyzed is ground (for about $1 \mathrm{~min}$ ) using a sample mill (Aldrich/Sigma Saint Louis, MO 63178-9916). A tobacco sample of $125 \mathrm{mg}$ is weighed with a precision of $\pm 0.1 \mathrm{mg}$ in a vial that can accommodate at least $15 \mathrm{~mL}$ of solution (20 mL crimp top vials, Supelco, Bellefonte, PA 16823 were used in this work). To this sample, $10 \mathrm{~mL}$ of $0.1 \mathrm{~N}$ $\mathrm{HCl}$ in water containing $5 \mathrm{mg} / \mathrm{mL}$ of phenylglycine (Aldich/Sigma, Saint Louis, MO 63178-9916) used as internal standard (I.S.) is added. Phenylglycine is not present in tobacco and it is not one of the important natural amino acids. After capping the vial, the extraction is performed for $1 \mathrm{~h}$ at room temperature using a mechanical shaker. Longer extraction times (up to $2 \mathrm{~h}$ ) do not influence the results of the analysis. The extract is filtered through a $0.45 \mathrm{~mm}$ PTFE filter (VWR, Suwanee, GA 30024) into a test tube and used for sample cleanup.

\section{Digestion of tobacco proteins for total amino acid analysis}

For the analysis of total amino acids from a tobacco sample, a $125 \mathrm{mg}$ sample is weighed with a precision of $\pm 0.1 \mathrm{mg}$ in a vial that can accommodate at least $15 \mathrm{~mL}$ solution. Identical vials to those needed for free amino acid extraction were used in this work. A smaller amount of starting material can be taken for analysis, and the whole procedure can be scaled down proportionally. However, for smaller quantities of tobacco the homogenization process of the sample and specifically the grinding of the tobacco must be done in such a way that a representative sample is obtained. Tobacco leaf as well as tobacco blends from cigarettes are not highly homogeneous and a small and nonhomogeneous sample may lead to incorrect results. To the tobacco is added $250 \mu \mathrm{L}$ of a solution of I.S. phenylglycine in water having a concentration of $200 \mu \mathrm{g} / \mathrm{mL}$. The final quantity of I.S. for $125 \mathrm{mg}$ tobacco is $50 \mu \mathrm{g}$, identical to the amount added for free amino acid analysis. For the digestion, $2 \mathrm{~mL}$ of $6 \mathrm{~N} \mathrm{HCl}$ containing $1 \%$ phenol (Aldich/Sigma Saint Louis, MO 63178-9916) is added. The vial containing the sample, the I.S., and the acid is sealed and inserted into a microwave permeable digestion tube. The microwave used in this experiment was a MarsX instrument from CEM Corp., Matthews, NC 28106. The sample was digested for $2 \mathrm{~h}$ at $120{ }^{\circ} \mathrm{C}(1200 \mathrm{~W}$ power, 2 min ramping time). After the samples are cooled to room temperature, the contents of the sample vial and of the digestion tube are transferred using no more than $8 \mathrm{~mL}$ of water, into a PTFE filter cartridge with $0.45 \mu \mathrm{m}$ pores and filtered into a test tube. The material from the sample vial and digestion tube cannot always be transferred quantitatively. However, the presence of the internal standard compensates for small losses during the transfer. The resulting solution has a very low $\mathrm{pH}$. The high content of $\mathrm{HCl}$ in the solution may be eliminated by evaporation if necessary, for example, when using a Zymark Rapid Trace automatic SPE system that has metal parts in contact with the sample solution. For this purpose, the solution containing the digested material is evaporated using a TurboVap LV evaporator (Zymark, Hopkinton, MA 01748) at $75{ }^{\circ} \mathrm{C}$ under a flow of air (for about $45 \mathrm{~min}$ ). The resulting solid residue can be reextracted for $15 \mathrm{~min}$ with $10 \mathrm{~mL}$ of $0.1 \mathrm{~N} \mathrm{HCl}$ using a mechanical shaker, and the solution is further used for sample cleanup. The elimination of the excess of $\mathrm{HCl}$ is not necessary if no metal parts are used during the SPE processing step.

\section{Sample cleanup}

The sample solution containing the amino acids, either from a standard mixture, from free amino acid extraction, or from the microwave digestion of the tobacco sample is subjected to a cleanup procedure which consists of passing the sample through a SPE strong cation exchange column (CUBRX8 from UCT, Bristol, PA 19007). After the column is conditioned with $0.1 \mathrm{~N} \mathrm{HCl}$ in water, the sample is added to the column, washed with water, followed by the elution of the amino acids with a $1 \mathrm{~N}$ solution of $\mathrm{NH}_{4} \mathrm{OH}$ (Aldich/Sigma Saint Louis, MO 63178-9916). The procedure uses a Zymark Rapid Trace automatic SPE system (Zymark, Hopkinton, MA 01748). The conditions for the Rapid Trace system are given in Table 1. The three fractions collected from the Rapid Trace system are partly evaporated, combined, and further evaporated to dryness using a TurboVap LV evaporator at $75^{\circ} \mathrm{C}$ under a flow of air (for about $45 \mathrm{~min}$ ). The SPE cartridges are reusable after regeneration with $0.1 \mathrm{~N} \mathrm{HCl}$.

\section{Sample derivatization}

The derivatization of the sample is done directly in the test tubes in which the solutions were evaporated using the TurboVap. For this purpose, to each test tube are added $0.2 \mathrm{~mL}$ dimethylformamide (DMF), $0.2 \mathrm{~mL}$ pyridine, and $0.4 \mathrm{~mL}$ MTBSTFA. The test tubes are stoppered (with a rubber stopper) and heated for $30 \mathrm{~min}$ in a heating block at $80{ }^{\circ} \mathrm{C}$. After this period the reaction is completed. The solution is allowed to cool to room temperature (for about 
Table 2. GC-MS operating parameters ${ }^{a}$

\begin{tabular}{|c|c|c|c|}
\hline Parameter & Description & Parameter & Description \\
\hline GC column & DB-5MS or equivalent & Carrier gas & Helium \\
\hline Column dimensions & $30 \mathrm{~m}$ long, $0.25 \mathrm{~mm}$ i.d. & Flow mode & Constant flow \\
\hline Film thickness & $0.25 \mu \mathrm{m}$ & Flow rate & $1.0 \mathrm{~mL} / \mathrm{min}$ \\
\hline Initial oven temperature & $50^{\circ} \mathrm{C}$ & Nominal initial pressure & 7.57 psi \\
\hline Initial time & $0.5 \min$ & Split ratio & $30: 1$ \\
\hline Oven ramp rate & $3{ }^{\circ} \mathrm{C} / \mathrm{min}$ & Split flow & $29.8 \mathrm{~mL} / \mathrm{min}$ \\
\hline Oven final first ramp & $200{ }^{\circ} \mathrm{C}$ & GC outlet & MSD \\
\hline Final time first ramp & $0 \mathrm{~min}$ & Outlet pressure & Vacuum \\
\hline Oven ramp rate & $4{ }^{\circ} \mathrm{C} / \mathrm{min}$ & MSD transfer line & $280{ }^{\circ} \mathrm{C}$ \\
\hline Oven final temperature & $300{ }^{\circ} \mathrm{C}$ & Ion source temperature & $230^{\circ} \mathrm{C}$ \\
\hline Final time & $10 \mathrm{~min}$ & Quadrupole temp. & $150^{\circ} \mathrm{C}$ \\
\hline Total run time & $85.5 \min$ & MSD EM offset & 100 V \\
\hline Inlet temperature & $300{ }^{\circ} \mathrm{C}$ & MSD solvent delay & $18.0 \mathrm{~min}$ \\
\hline Inlet mode & Split & MSD acquisition mode & TIC \\
\hline Injection volume & $1.0 \mu \mathrm{L}$ & & \\
\hline
\end{tabular}

${ }^{\text {a }}$ Abbreviations: MSD = mass selective detector; TIC = total ion chromatogram..

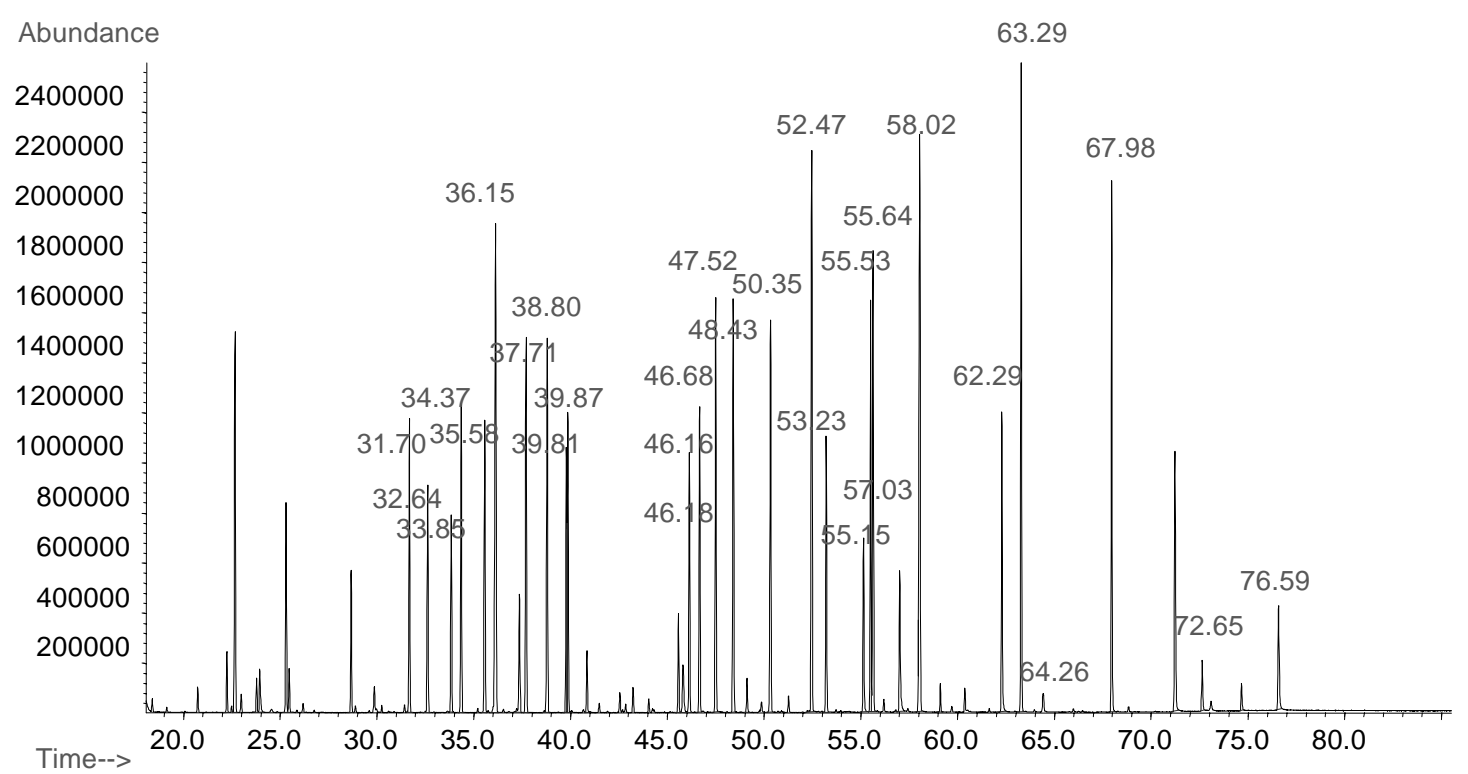

Figure 2. Chromatogram for a standard mixture of amino acids and urea. The concentration for the solution used for the Rapid Trace system was $0.05 \mu \mathrm{mol} / \mathrm{mL}$ of each amino acid (except for 2-phenylglycine used as the internal standard). Norleucine was not present in the standard mixture.

$15 \mathrm{~min}$ ) and transferred into a GC vial (2 $\mathrm{mL}$ screw top vials with screw caps with septa, Agilent, Wilmington, Delaware 19808, were used in this work).

\section{GC-MS analysis}

The analysis of $t$-butyldimethylsilyl (TBDMS) derivatives of amino acids is done using a GC-MS instrument (such as the Agilent 6890/5973 system from Agilent, Wilmington, Delaware 19808). The parameters for the analysis are given in Table 2. The use of the SPE cleanup, the derivatization, and the GC-MS analysis using the parameters given in Table 2 generate the chromatogram shown in Figure 2 for an amino acid standard mixture. Amino acid standard solutions are available at $2.5 \mu \mathrm{mol} / \mathrm{mL}$ concentration of each amino acid as acidic plus neutral ones and also containing urea (Product No. A 6407 Sigma, Saint Louis, MO 63178-9916), and basic amino acids (Product No. A 6282 Sigma, Saint Louis, MO 63178-9916). The concentration of the sample solution used for the Rapid Trace system was $0.05 \mu \mathrm{mol} / \mathrm{mL}$ of each amino acid and was obtained by adding in $9.6 \mathrm{~mL}$ water and $200 \mu \mathrm{L}$ of the two standard solutions. (At 100\% transfer through the $\mathrm{SPE}$, this corresponds to $0.2 \mu \mathrm{mol}$ compound to be derivatized). The identification of the amino acids can be done based on their mass spectra and retention times. Table 3 gives the list of analyzed amino acids, one of their characteristic ions, which has been used for quantitation, and the specific chromatographic retention times. Because the mass spectrum of TBDMS derivative of 2-phenylglycine is not reported in the literature, it is shown in Figure 3. 
Table 3. List of amino acids, one of their characteristic ions used for quantitation and the chromatographic retention times

\begin{tabular}{|c|c|c|c|c|c|c|}
\hline Peak no. & Amino acid & MW & Formula $+x$ TBDMS & $\mathrm{MW}+\mathrm{x}$ TBDMS & Characteristic ion & Retention time \\
\hline 1 & $\alpha$-Alanine & 89.09 & $\mathrm{C}_{15} \mathrm{H}_{35} \mathrm{NO}_{2} \mathrm{Si}_{2}$ & 317 & 260 & 31.69 \\
\hline 2 & Glycine & 75.07 & $\mathrm{C}_{14} \mathrm{H}_{33} \mathrm{NO}_{2} \mathrm{Si}_{2}$ & 303 & 246 & 32.63 \\
\hline 3 & Sarcosine & 89.09 & $\mathrm{C}_{15} \mathrm{H}_{35} \mathrm{NO}_{2} \mathrm{Si}_{2}$ & 317 & 260 & 33.85 \\
\hline 4 & $\alpha$-Amino- $n$-butyric acid & 103.10 & $\mathrm{C}_{16} \mathrm{H}_{37} \mathrm{NO}_{2} \mathrm{Si}_{2}$ & 331 & 274 & 34.36 \\
\hline 5 & $\beta$-Alanine & 89.09 & $\mathrm{C}_{15} \mathrm{H}_{35} \mathrm{NO}_{2} \mathrm{Si}_{2}$ & 317 & 260 & 35.58 \\
\hline 6 & Urea & 60.06 & $\mathrm{C}_{13} \mathrm{H}_{32} \mathrm{~N}_{2} \mathrm{OSi}_{2}$ & 288 & 231 & 36.01 \\
\hline 7 & $\beta$-Aminoisobutyric acid & 103.10 & $\mathrm{C}_{16} \mathrm{H}_{37} \mathrm{NO}_{2} \mathrm{Si}_{2}$ & 331 & 274 & 36.11 \\
\hline 8 & Valine & 117.15 & $\mathrm{C}_{17} \mathrm{H}_{39} \mathrm{NO}_{2} \mathrm{Si}_{2}$ & 345 & 186 & 36.15 \\
\hline 9 & Leucine & 131.17 & $\mathrm{C}_{18} \mathrm{H}_{41} \mathrm{NO}_{2} \mathrm{Si}_{2}$ & 359 & 200 & 37.71 \\
\hline 10 & Norleucine & 131.17 & $\mathrm{C}_{18} \mathrm{H}_{41} \mathrm{NO}_{2} \mathrm{Si}_{2}$ & 359 & 200 & 38.66 \\
\hline 11 & Isoleucine & 131.17 & $\mathrm{C}_{18} \mathrm{H}_{41} \mathrm{NO}_{2} \mathrm{Si}_{2}$ & 359 & 200 & 38.79 \\
\hline 12 & $\mathrm{Y}$-Aminobutyric acid & 103.10 & $\mathrm{C}_{16} \mathrm{H}_{37} \mathrm{NO}_{2} \mathrm{Si}_{2}$ & 331 & 274 & 39.79 \\
\hline 13 & Proline & 115.13 & $\mathrm{C}_{17} \mathrm{H}_{37} \mathrm{NO}_{2} \mathrm{Si}_{2}$ & 343 & 184 & 39.87 \\
\hline 14 & 2-Phenylglycine (I.S) & 151.17 & $\mathrm{C}_{20} \mathrm{H}_{37} \mathrm{NO}_{2} \mathrm{Si}_{2}$ & 379 & 220 & 46.16 \\
\hline 15 & 5-Oxoproline & 129.13 & $\mathrm{C}_{17} \mathrm{H}_{35} \mathrm{NO}_{3} \mathrm{Si}_{2}$ & 357 & 300 & 46.18 \\
\hline 16 & Methionine & 149.20 & $\mathrm{C}_{17} \mathrm{H}_{39} \mathrm{NO}_{2} \mathrm{SSi}_{2}$ & 377 & 320 & 46.68 \\
\hline 17 & Serine & 105.09 & $\mathrm{C}_{21} \mathrm{H}_{49} \mathrm{NO}_{3} \mathrm{Si}_{3}$ & 447 & 390 & 47.52 \\
\hline 18 & Threonine & 119.12 & $\mathrm{C}_{22} \mathrm{H}_{51} \mathrm{NO}_{3} \mathrm{Si}_{3}$ & 461 & 404 & 48.43 \\
\hline 19 & Phenylalanine & 165.19 & $\mathrm{C}_{21} \mathrm{H}_{39} \mathrm{NO}_{2} \mathrm{Si}_{2}$ & 393 & 336 & 50.35 \\
\hline 20 & Aspartic acid & 133.10 & $\mathrm{C}_{22} \mathrm{H}_{49} \mathrm{NO}_{4} \mathrm{Si}_{3}$ & 475 & 418 & 52.47 \\
\hline 21 & Hydroxyproline & 131.13 & $\mathrm{C}_{23} \mathrm{H}_{51} \mathrm{NO}_{3} \mathrm{Si}_{3}$ & 473 & 314 & 53.23 \\
\hline 22 & 3-Methyl-L-histidine & 169.20 & $\mathrm{C}_{19} \mathrm{H}_{39} \mathrm{~N}_{3} \mathrm{O}_{2} \mathrm{Si}_{2}$ & 397 & 340 & 55.15 \\
\hline 23 & Glutamic acid & 147.13 & $\mathrm{C}_{23} \mathrm{H}_{51} \mathrm{NO}_{4} \mathrm{Si}_{3}$ & 489 & 432 & 55.53 \\
\hline 24 & Ornithine & 132.20 & $\mathrm{C}_{23} \mathrm{H}_{54} \mathrm{~N}_{2} \mathrm{O}_{2} \mathrm{Si}_{3}$ & 474 & 286 & 55.64 \\
\hline 25 & 1-Methyl-L-histidine & 169.20 & $\mathrm{C}_{19} \mathrm{H}_{39} \mathrm{~N}_{3} \mathrm{O}_{2} \mathrm{Si}_{2}$ & 397 & 302 & 57.03 \\
\hline 26 & Lysine & 146.19 & $\mathrm{C}_{24} \mathrm{H}_{56} \mathrm{~N}_{2} \mathrm{O}_{2} \mathrm{Si}_{3}$ & 488 & 300 & 58.02 \\
\hline 27 & $\alpha$-Aminoadipic acid & 161.20 & $\mathrm{C}_{24} \mathrm{H}_{53} \mathrm{NO}_{4} \mathrm{Si}_{3}$ & 503 & 446 & 58.06 \\
\hline 28 & Histidine & 155.16 & $\mathrm{C}_{24} \mathrm{H}_{51} \mathrm{~N}_{3} \mathrm{O}_{2} \mathrm{Si}_{3}$ & 497 & 440 & 62.29 \\
\hline 29 & Tyrosine & 181.19 & $\mathrm{C}_{27} \mathrm{H}_{53} \mathrm{NO}_{3} \mathrm{Si}_{3}$ & 523 & 302 & 63.29 \\
\hline 30 & Arginine & 174.20 & $\mathrm{C}_{24} \mathrm{H}_{56} \mathrm{~N}_{4} \mathrm{O}_{2} \mathrm{Si}_{3}$ & 516 & 144 & 64.26 \\
\hline 31 & Tryptophan & 204.22 & $\mathrm{C}_{29} \mathrm{H}_{54} \mathrm{~N}_{2} \mathrm{O}_{2} \mathrm{Si}_{3}$ & 546 & 244 & 67.98 \\
\hline 32 & Cystine & 240.30 & $\mathrm{C}_{28} \mathrm{H}_{64} \mathrm{~N}_{2} \mathrm{O}_{4} \mathrm{~S}_{2} \mathrm{Si}_{4}$ & 668 & 348 & 72.65 \\
\hline 33 & Homocystine & 268.30 & $\mathrm{C}_{32} \mathrm{H}_{72} \mathrm{~N}_{2} \mathrm{O}_{4} \mathrm{~S}_{2} \mathrm{Si}_{4}$ & 724 & 362 & 76.59 \\
\hline
\end{tabular}

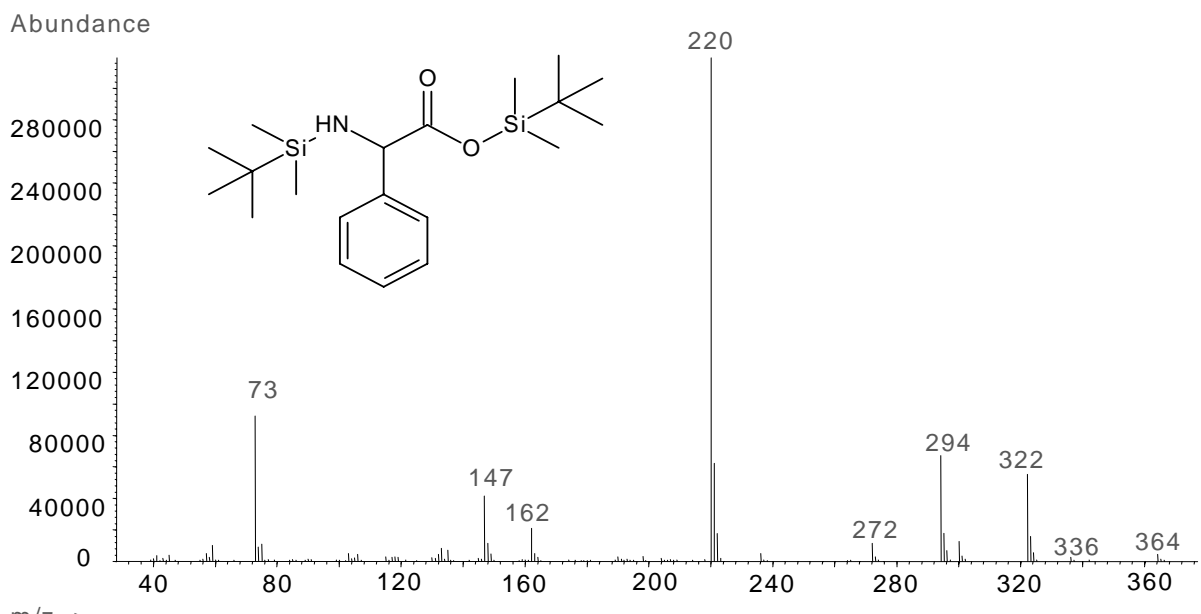

Figure 3. The mass spectrum of $t$-butyldimethylsilyl derivative of 2-phenylglycine

As seen from Figure 2, the GC-MS response of the individual amino acids is not equal. Particularly, arginine, cystine, and homocystine have a relatively low response. Asparagine and glutamine are not even seen in the chromatogram in Figure 2 (although present in the sample) and are not listed in Table 3. Under the conditions for the protein hydrolysis, asparagine and glutamine are hydrolyzed to form aspartic acid and glutamic acid, respectively.

A typical chromatogram for the free amino acids from a 2R4F tobacco blend is given in Figure 4, and that for total 


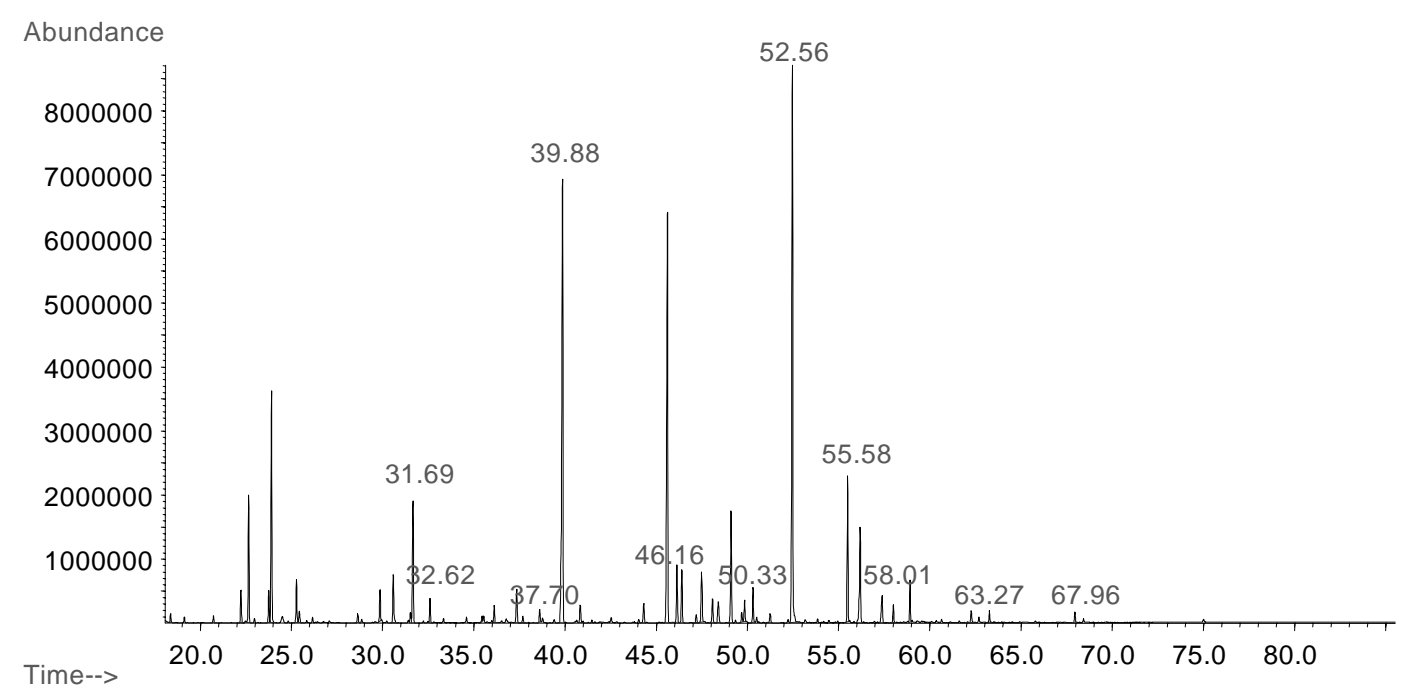

Figure 4. Typical chromatogram for the free amino acids in a tobacco blend (from Kentucky reference 2R4F cigarette). Specific amino acids were identified based on their mass spectra and the retention times matching those given in Table 3.

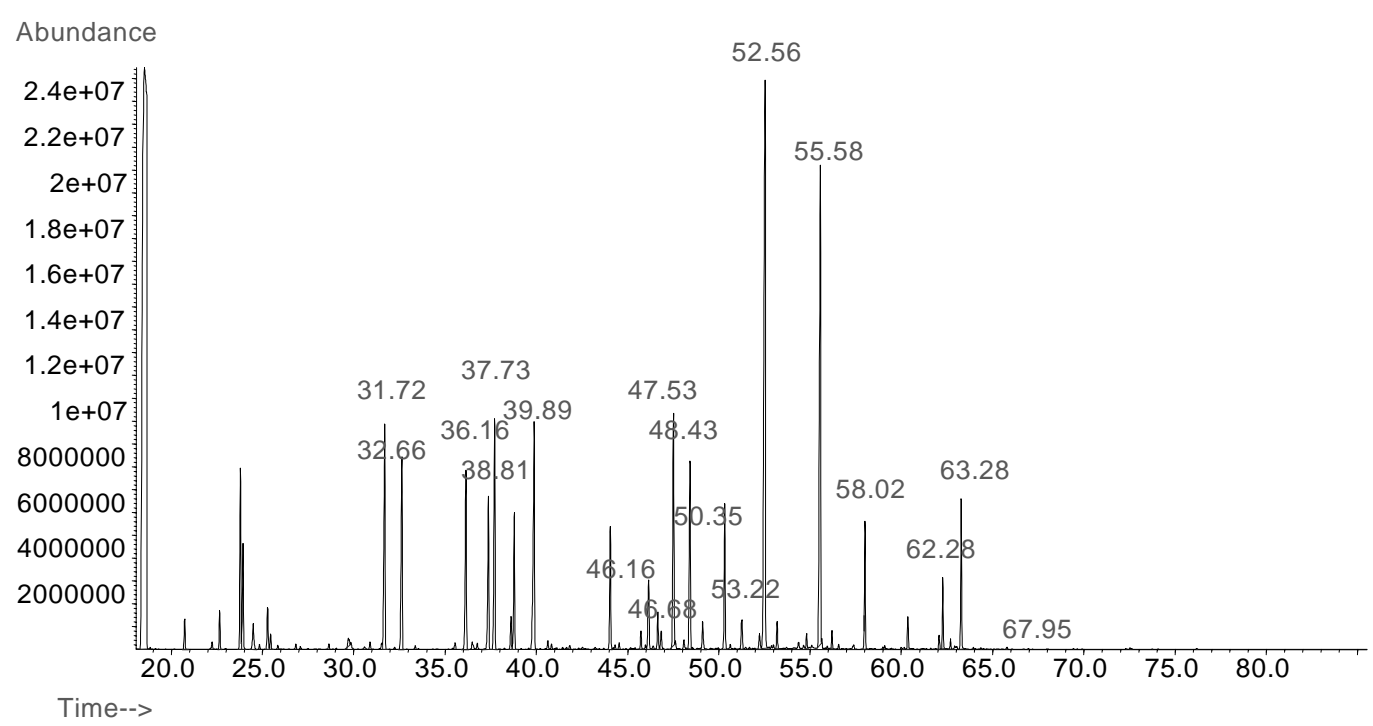

Figure 5. Typical chromatogram for the total amino acids in a tobacco blend (from Kentucky reference 2R4F cigarette). Specific amino acids were identified based on their mass spectra and the retention times matching those given in Table 3.

amino acids from the 2R4F blend is given in Figure 5. As it can be seen from these figures, the total intensities as well as the relative intensities of the peaks for individual amino acids are different between the free and total amino acid chromatograms.

\section{Amino acid quantitation}

For the quantitation of each amino acid, the peak area of a characteristic extracted ion normalized by the peak area of the ion with $\mathrm{m} / \mathrm{z}=220$ of the I.S. was represented as a function of the amino acid concentration. The calibration curves were generated in the concentration range of the sample solution (further processed by the SPE cleanup step) between $0.02 \mu \mathrm{g} / \mathrm{mL}$ and $10 \mu \mathrm{g} / \mathrm{mL}$ (in the sampling solution). The characteristic ion used for the quantitation for each amino acid is given in Table 3. The calibrations are linear between $0.1 \mu \mathrm{g} / \mathrm{mL}$ and at least $0.1 \mathrm{mg} / \mathrm{mL}$ of the sampling solution. However, below this concentration the calibration curve is not linear. As an example, the calibration curve for alanine for the whole calibration interval is shown in Figure 6 and that for the range $0.02 \mu \mathrm{g} / \mathrm{mL}$ to 1.0 $\mu \mathrm{g} / \mathrm{mL}$ is shown in Figure 7.

All the analyzed amino acids showed a very similar behavior, and the deviation from linearity started to be seen below $0.1 \mu \mathrm{g} / \mathrm{mL}$ (in the sampling solution) for all amino acids. This concentration corresponds, under the experimental conditions used in this study, to a level of $0.008 \mathrm{mg} / \mathrm{g}$ of each amino acid in the tobacco sample. The causes were not determined for the nonlinear response at low concentrations. However, the reduction of the volumes of the solvent and of the derivatization reagent leads to a linear curve for a lower concentration in the sampling solution. This indicates that, by scaling appropriately the 


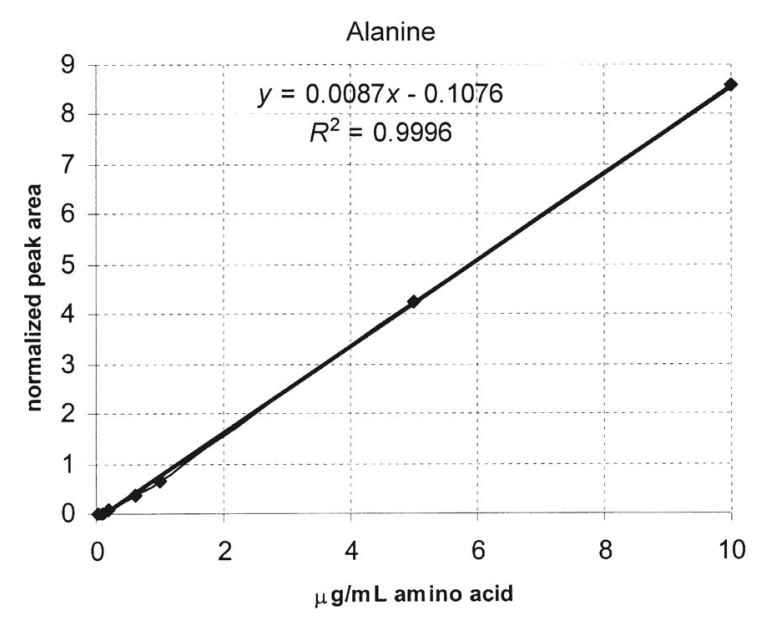

Figure 6. Calibration curve for alanine in the range $0.02 \mu \mathrm{g} / \mathrm{mL}$ and $10 \mu \mathrm{g} / \mathrm{mL}$. The concentration is given for the sampling solution. (The trendline and its equation are also shown.)

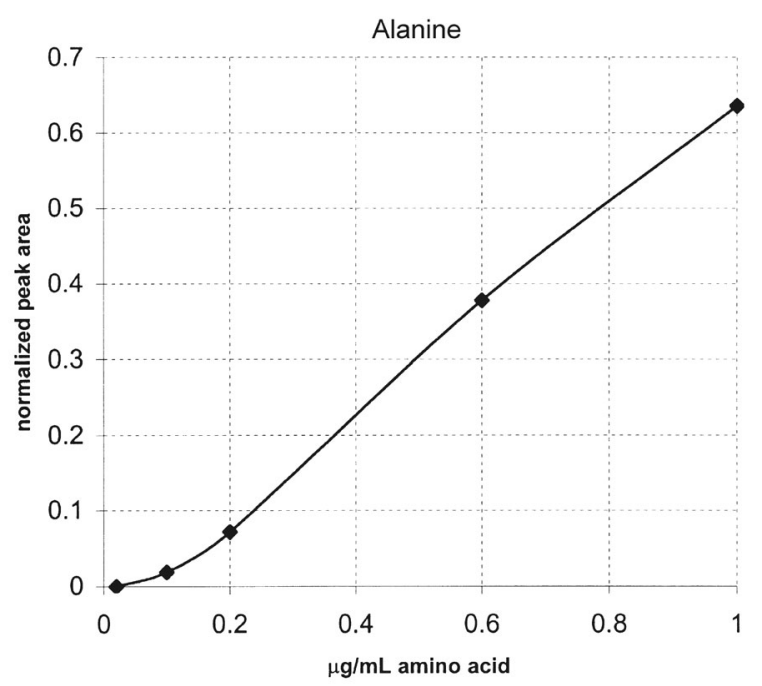

Figure 7. Calibration curve for alanine in the range $0.02 \mu \mathrm{g} / \mathrm{mL}$ and $1 \mu \mathrm{g} / \mathrm{mL}$. The concentration is given for the sampling solution. (The linear curve represents the trendline for all the data.)

amount of the initial tobacco sample and the conditions for the derivatization, the method can be applied to the analysis of at least 5-fold lower levels of amino acids. In spite of this, the conditions of analysis previously described were used without sensitivity improvement because the achieved sensitivity was considered adequate for the purpose of this study. The results of the analysis were calculated from the linear dependence generated for each amino acid, and further reported to the amount of tobacco used in the analysis.

Because tobacco samples typically have a certain moisture level, the result can be reported to the amount of tobacco as is, or can be reported on a dry tobacco basis (DB). To report the result on DB it is possible to use several alternative procedures. One procedure consists of the measurement of the water content in a separate sample using a GC procedure, and in accounting for this water when calculating the result. An alternative method is the determination of water as oven moisture. Although this procedure is simple and frequently used in the tobacco industry, it overestimates the water content by including other volatiles in the moisture level. Another procedure is to use air dried samples for analysis. This procedure always leaves a certain amount of water in the sample. For tobacco from cigarettes which may have been treated with humectants such as glycerin, the use of air drying and reporting the results on DB is questionable. However, for the analysis of amino acids in this study, the results were reported on DB using air dried tobaccos.

\section{RESULTS AND DISCUSSION}

Several aspects regarding the determination of total amino acids in tobacco were evaluated and/or optimized in this study. The first was the selection of a suitable analytical method for amino acid analysis in the complex mixture generated by extracting tobacco. The second was the optimization of the microwave digestion procedure. The last was the generation of the results for specific single grade tobaccos and for tobaccos from Kentucky reference cigarettes. These subjects are further discussed in more detail.

\section{Selection and implementation of the method for amino acid analysis}

The main criterion for the selection of an amino acid analysis technique was the capability of an accurate identification of each amino acid. This requirement was needed because the nature of the amino acids in tobacco proteins is an important issue, even if they are at low levels. The detection technique of choice was therefore mass spectrometry. Although LC-MS was considered a viable alternative, instrument availability was an issue. While LCMS instrumentation is becoming relatively common, this type of equipment is still missing in many laboratories. For this reason, a GC-MS method of analysis was preferred. The lack of technical details on the EZ:faast ${ }^{\mathrm{TM}}$ method (available from Phenomenex) limited the choice to the derivatization with pentafluoropropionic anhydride (PFPA) and isopropanol + acetyl chloride (PFP-IP derivatization method) and the derivatization with $N$-methyl- $N$-( $t$-butyldimethylsilyl)-trifluoroacetamide (MTBSTFA derivatization method). Because the PFP-IP method requires two derivatization steps, the MTBSTFA method was the final choice. The original MTBSTFA method was modified in this study compared to the original procedure (15) by using as a solvent a $50 / 50(\mathrm{v} / \mathrm{v})$ mixture of DMF and pyridine. Also, an equal volume of solvent and reagent (MTBSTFA) was used. The relatively high volume of solvent (DMF + pyridine) relative to the reagent was selected because the reagent itself is not a very good solvent for the amino acids and better results regarding repeatability were obtained with this modified solvent/reagent ratio. Because the elements for the validation of the analytical method using MTBSTFA are reported in literature (15), and the method was proven to have very good repeatability with \%RSD values typically lower than $2 \%$, no further evaluation of the method as applied to standards was performed.

One shortcoming of the method selected for the amino acid analysis is that it is not directly applicable for asparagine and glutamine. These compounds are not seen in the chromatogram, although they are present in the sample. 


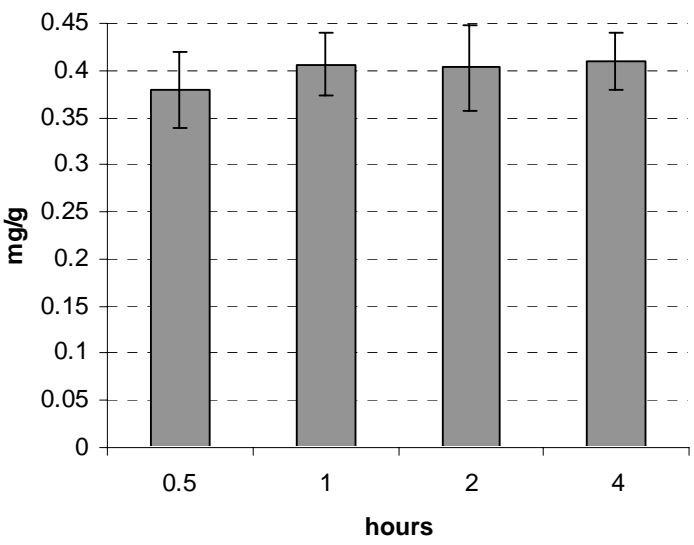

Figure 8. Variation in the level of measured free alanine for different extraction times of $2 \mathrm{R} 4 \mathrm{~F}$ tobacco blend with $0.1 \mathrm{NHCl}$

Both asparagine and glutamine can be hydrolyzed with $6 \mathrm{~N}$ $\mathrm{HCl}$ for one hour at room temperature, and the resulting aspartic acid and glutamic acid analyzed after derivatization. Because the conditions for protein hydrolysis are much stronger than those necessary for the hydrolysis of asparagine and glutamine, it is not possible to identify these amino acids in the protein hydrolysate. Therefore, even knowing the level of free asparagine and glutamine it is not possible to determine their level as protein amino acids when using protein hydrolysis.

\section{The analysis of free amino acids in tobacco}

Several tobacco samples were analyzed for free amino acid content. These included cigarette tobaccos from four Kentucky reference cigarettes, namely $1 \mathrm{R} 1,1 \mathrm{R} 3 \mathrm{~F}, 1 \mathrm{R} 5 \mathrm{~F}$, and $2 \mathrm{R} 4 \mathrm{~F}$ as well as several single type tobaccos including one Oriental, one burley, and five flue-cured samples. The evaluation of the efficiency of the extraction procedure and of the recovery using the cleanup procedure were studied only for the 2R4F blend. For the extraction efficiency, $125 \mathrm{mg}$ of tobacco was extracted with $10 \mathrm{~mL} 0.1 \mathrm{~N} \mathrm{HCl}$ (containing the internal standard) for $30 \mathrm{~min}$, one hour, two hours, and four hours. The extraction time for the amino acids from tobacco recommended in literature varies from several hours up to 51 hours (4). The results showing the variation in the level of measured alanine for different extraction times of $2 \mathrm{R} 4 \mathrm{~F}$ tobacco blend are shown in Figure 8.

Similar variations were seen for all the other amino acids, except for aspartic acid and glutamic acid, which showed a slightly larger increase for four hours extraction. The longer extraction of tobacco can be associated with some hydrolysis of asparagine and glutamine and this may explain the slightly higher increase seen in the levels of the aspartic acid and glutamic acid compared to that of other amino acids. Because the variation in the levels of amino acids between one hour and four hours extraction time was within the error of the analytical procedure, all samples were extracted for the analysis of free amino acids for only one hour. A longer extraction time is not justified because the extraction of tobacco samples for one hour has been proven sufficient for many other analytes in tobacco (27).
Table 4. Recovery evaluation for a standard mixture of amino acids and urea

\begin{tabular}{|c|c|c|c|c|}
\hline $\begin{array}{l}\text { Peak } \\
\text { No. }\end{array}$ & Amino acid & $\begin{array}{c}\text { Area count } \\
\text { from SPE }\end{array}$ & $\begin{array}{l}\text { Area count } \\
\text { direct deriv. }\end{array}$ & $\begin{array}{c}\text { Recovery } \\
\%\end{array}$ \\
\hline 1 & $\alpha$-Alanine & 4138695 & 4109975 & 100.7 \\
\hline 27 & $\alpha$-Aminoadipic acid & 7686616 & 7966594 & 96.5 \\
\hline 4 & $\alpha$-Aminobutyric acid & 4098667 & 4210238 & 97.4 \\
\hline 30 & Arginine & 230894 & 267547 & 86.3 \\
\hline 20 & Aspartic acid & 4453715 & 6291401 & 70.8 \\
\hline 5 & $\beta$-Alanine & 3152375 & 3373937 & 93.4 \\
\hline 7 & $\begin{array}{l}\beta \text {-Aminoisobutyric } \\
\text { acid }\end{array}$ & 2727454 & 2989164 & 91.2 \\
\hline 32 & Cystine & 37314 & 140751 & 26.5 \\
\hline 12 & Y-Aminobutyric acid & 6174500 & 6763256 & 91.3 \\
\hline 23 & Glutamic acid & 7738406 & 8057323 & 96.0 \\
\hline 2 & Glycine & 3228239 & 3631927 & 88.9 \\
\hline 28 & Histidine & 5329365 & 6233800 & 85.5 \\
\hline 33 & Homocystine & 895863 & 1292111 & 69.3 \\
\hline 21 & Hydroxyproline & 16399342 & 14429252 & 113.7 \\
\hline 11 & Isoleucine & 13049761 & 13332480 & 97.9 \\
\hline 9 & Leucine & 14391758 & 14805626 & 97.2 \\
\hline 26 & Lysine & 3181974 & 3827678 & 83.1 \\
\hline 16 & Methionine & 3801963 & 3949352 & 96.3 \\
\hline 22 & 3-Methyl-L-histidine & 4187712 & 4356579 & 96.1 \\
\hline 25 & 1-Methyl-L-histidine & 4289133 & 5080958 & 84.4 \\
\hline 10 & Norleucine & 13049766 & 13338824 & 97.8 \\
\hline 24 & Ornithine & 5410482 & 7031903 & 76.9 \\
\hline 15 & Oxoproline & - & - & - \\
\hline 19 & Phenylalanine & 4143413 & 4311566 & 96.1 \\
\hline 14 & 2-Phenylglycine (I.S) & 10376023 & 11452748 & 90.6 \\
\hline 13 & Proline & 14497306 & 14565891 & 99.5 \\
\hline 3 & Sarcosine & 2265332 & 2249136 & 100.7 \\
\hline 17 & Serine & 6349308 & 6487253 & 97.9 \\
\hline 18 & Threonine & 4032538 & 4120946 & 97.9 \\
\hline 31 & Tryptophan & 26706098 & 27795912 & 96.1 \\
\hline 29 & Tyrosine & 26178035 & 27444755 & 95.4 \\
\hline 6 & Urea & 96257 & 91397 & 105.3 \\
\hline 8 & Valine & 11987652 & 12283852 & 97.6 \\
\hline
\end{tabular}

A possible slight increase with extraction time in the analysis results for amino acids may be due to some protein hydrolysis that can occur during prolonged extractions with $0.1 \mathrm{~N} \mathrm{HCl}$.

Another parameter evaluated for the analytical procedure used for the measurement of free amino acids in tobacco was analyte recovery during the cleanup step. For this purpose, $4 \mathrm{~mL}$ of a solution containing a mixture of amino acids was processed using the SPE cleanup procedure. As a control, $4 \mathrm{~mL}$ of the same solution was evaporated, derivatized, and analyzed. The results for recovery evaluation are shown in Table 4. The concentration of the solution used for the Rapid Trace system and of the solution for control was $0.05 \mu \mathrm{mmol} / \mathrm{mL}$ of each amino acid (except for 2-phenylglycine used as internal standard). The table gives the area counts for the chromatographic peaks generated by the standard mixture of amino acids, with and without SPE cleanup, and the ratios of corresponding areas. The results were evaluated for only one replicate and some variation from sample to sample is possible. However, the results show that the recoveries are good for most amino acids, and because the quantitation of amino acids is based on nor- 
Table 5. Levels expressed in $\mathrm{mg} / \mathrm{g}$ (free amino acid/tobacco) for three different flue-cured tobaccos using the method described in this study and also with the analysis previously done using an HPLC procedure (28)

\begin{tabular}{|c|c|c|c|c|c|c|c|c|c|c|}
\hline \multirow[b]{2}{*}{ Peak no. } & \multirow[b]{2}{*}{ Compound } & \multicolumn{3}{|c|}{ Flue-cured 1} & \multicolumn{3}{|c|}{ Flue-cured 2} & \multicolumn{3}{|c|}{ Flue-cured 3} \\
\hline & & Average $^{\mathrm{a}}$ & $\mathrm{RSD} \%$ & Known $^{\mathrm{b}}$ & Average $^{\mathrm{a}}$ & $\mathrm{RSD} \%$ & Known $^{\mathrm{b}}$ & Average $^{\mathrm{a}}$ & $\mathrm{RSD} \%$ & Known $^{b}$ \\
\hline 1 & $\alpha$-Alanine & 1.22 & 0.46 & 1.30 & 0.89 & 1.01 & 0.74 & 0.65 & 1.09 & 0.39 \\
\hline 27 & $\alpha$-Aminoadipic acid & $>0.01$ & 3.35 & - & $>0.01$ & 3.40 & - & - & - & - \\
\hline 4 & $\alpha$-Aminobutyric acid & $>0.01$ & 0.06 & - & $>0.01$ & 14.43 & - & - & - & - \\
\hline 30 & Arginine & 0.34 & 3.22 & 0.70 & 0.16 & 4.22 & 0.35 & 0.21 & 6.12 & 0.35 \\
\hline 20 & Aspartic acid & 0.61 & 2.87 & 0.88 & 0.48 & 6.25 & 0.51 & 0.73 & 3.97 & 0.61 \\
\hline 5 & $\beta$-Alanine & 0.02 & 4.88 & - & 0.01 & 3.56 & - & 0.01 & 6.08 & - \\
\hline 7 & $\beta$-Aminoisobutyric acid & - & - & - & - & - & - & - & - & - \\
\hline 32 & Cystine & - & - & - & - & - & - & - & - & - \\
\hline 12 & Y-Aminobutyric acid & 0.08 & 4.33 & - & 0.07 & 4.55 & - & 0.05 & 2.52 & - \\
\hline 23 & Glutamic acid & 0.73 & 2.77 & 0.78 & 0.40 & 2.28 & 0.41 & 0.27 & 3.30 & 0.31 \\
\hline 2 & Glycine & 0.10 & 2.72 & 0.29 & 0.08 & 1.53 & 0.19 & 0.06 & 1.25 & 0.17 \\
\hline 28 & Histidine & 0.56 & 3.03 & 0.39 & 0.33 & 3.68 & 0.26 & 0.11 & 8.87 & 0.22 \\
\hline 33 & Homocystine & - & - & - & - & - & - & - & - & - \\
\hline 21 & Hydroxyproline & 0.01 & 0.59 & - & 0.01 & 0.77 & - & $>0.01$ & 1.09 & - \\
\hline 11 & Isoleucine & 0.12 & 7.33 & 0.05 & 0.06 & 3.02 & 0.03 & 0.06 & 6.44 & 0.03 \\
\hline 9 & Leucine & 0.02 & 1.63 & 0.03 & 0.02 & 7.54 & - & 0.02 & 4.87 & - \\
\hline 26 & Lysine & 0.07 & 5.35 & 0.18 & 0.11 & 2.13 & 0.13 & 0.08 & 3.72 & 0.10 \\
\hline 16 & Methionine & - & - & - & - & - & 0.01 & - & - & 0.01 \\
\hline 22 & 3-Methyl-L-histidine & 0.01 & 1.87 & - & 0.01 & 0.34 & - & 0.01 & 1.05 & - \\
\hline 25 & 1-Methyl-L-histidine & 0.02 & 1.92 & - & 0.02 & 5.84 & - & 0.02 & 0.54 & - \\
\hline 10 & Norleucine & 0.11 & 5.55 & - & 0.10 & 7.54 & - & 0.10 & 16.45 & - \\
\hline 24 & Ornithine & 0.01 & 10.23 & - & 0.01 & 6.28 & - & $>0.01$ & 9.76 & - \\
\hline 15 & Oxoproline & 0.20 & 3.81 & - & 0.17 & 9.56 & - & 0.03 & 4.21 & - \\
\hline 19 & Phenylalanine & 0.44 & 1.97 & 0.53 & 0.29 & 3.71 & 0.33 & 0.24 & 1.15 & 0.17 \\
\hline 14 & 2-Phenylglycine (I.S) & - & - & - & - & - & - & - & - & - \\
\hline 13 & Proline & 9.02 & 9.20 & 10.06 & 6.53 & 0.47 & 7.43 & 3.35 & 2.35 & 3.10 \\
\hline 3 & Sarcosine & - & - & - & - & - & - & - & - & - \\
\hline 17 & Serine & 0.41 & 2.77 & 0.58 & 0.31 & 5.37 & 0.43 & 0.11 & 2.10 & 0.19 \\
\hline 18 & Threonine & 0.30 & 3.58 & 0.30 & 0.18 & 8.69 & 0.18 & 0.04 & 1.18 & 0.06 \\
\hline 31 & Tryptophan & 0.60 & 0.87 & - & 0.54 & 0.77 & - & 0.16 & 8.38 & - \\
\hline 29 & Tyrosine & 0.11 & 2.88 & 0.16 & 0.09 & 6.91 & 0.13 & 0.09 & 1.42 & 0.09 \\
\hline 6 & Urea & - & - & - & - & - & - & - & - & - \\
\hline \multirow[t]{2}{*}{8} & Valine & 0.12 & 1.61 & 0.26 & 0.09 & 3.84 & 0.07 & 0.08 & 2.48 & 0.04 \\
\hline & SUM & 15.23 & & & 10.96 & & & 6.48 & & \\
\hline
\end{tabular}

\footnotetext{
${ }^{a}$ Averages in $\mathrm{mg} / \mathrm{g}$ of three replicates using the method described in this study.
}

${ }^{\mathrm{b}}$ Known values in $\mathrm{mg} / \mathrm{g}$ from an HPLC determination (28).

malized area counts (by the area of the internal standard) and not on absolute counts, unspecific losses during the cleanup procedure are compensated for. As seen from Table 4, only the results for cystine and homocystine show low recovery, and the recovery of oxoproline was not evaluated.

The results regarding the free amino acid content in three flue-cured samples are given in Table 5. The level of free amino acids was known in these samples from previous measurements using an HPLC method using derivatization with OPA and 9-fluorenylmethyl chloroformate $(28,29)$. Each sample was analyzed in triplicate.

As seen from Table 5, a reasonably good agreement exists between the results generated by the GC-MS method described in this study and the values from a previous HPLC determination $(28,30)$. The levels of glycine and arginine are lower using the GC-MS analysis compared to the HPLC analysis. The differences for the other values are within expected limits for agreement between two very different analytical techniques. The GC-MS technique also shows good repeatability as seen from the \%RSD values, which are lower than 5\% for all analyzed major amino acids. Only some of the amino acids, which are present at very low levels, show higher RSD values. The measurements indicating less than $0.01 \mathrm{mg} / \mathrm{g}$ correspond to a range in the nonlinear portion of the calibration curve and the errors for these measurements can be also caused by the deviation from the linear response. Table 6 gives the results of the analyzed free amino acids in other single tobacco type samples. Each sample was analyzed in triplicate.

The results from Tables 5 and 6 show that the sum of the levels of free amino acids in tobacco can be quite different depending on the grade as seen for the five different fluecured samples, and also may vary between tobacco types (flue-cured, burley, Oriental). The levels of individual amino acids show considerable differences between the tobacco types. These results are in good agreement with values reported in literature (20).

Table 7 gives the results in $\mathrm{mg} / \mathrm{g}$ of the analyzed free amino acids in the tobacco blend of several Kentucky reference cigarettes. Each result was obtained from three replicates except for the 2R4F tobacco blend with five replicates. The table shows that the sum of the levels of free amino acids in 
Table 6. Levels expressed in $\mathrm{mg} / \mathrm{g}$ (free amino acid/tobacco) for two different flue-cured tobaccos, an Oriental, and a burley

\begin{tabular}{|c|c|c|c|c|c|c|c|c|c|}
\hline \multirow[b]{2}{*}{ Peak no. } & \multirow[b]{2}{*}{ Amino acid } & \multicolumn{2}{|c|}{ Flue-cured 4} & \multicolumn{2}{|c|}{ Flue-cured 5} & \multicolumn{2}{|c|}{ Oriental } & \multicolumn{2}{|c|}{ Burley } \\
\hline & & Average & $\mathrm{RSD} \%$ & Average & $\mathrm{RSD} \%$ & Average & RSD\% & Average & $\mathrm{RSD} \%$ \\
\hline 1 & $\alpha$-Alanine & 0.62 & 2.23 & 0.68 & 1.87 & 0.83 & 3.50 & 0.43 & 0.32 \\
\hline 27 & $\alpha$-Aminoadipic acid & - & - & - & - & - & - & 0.02 & 0.91 \\
\hline 4 & $\alpha$-Aminobutyric acid & - & - & - & - & - & - & - & - \\
\hline 30 & Arginine & 0.23 & 3.26 & 0.21 & 7.11 & 0.19 & 5.55 & 0.14 & 4.28 \\
\hline 20 & Aspartic acid & 0.18 & 0.16 & 0.28 & 1.90 & 0.11 & 6.08 & 7.24 & 4.41 \\
\hline 5 & $\beta$-Alanine & 0.01 & 6.95 & 0.01 & 6.18 & 0.02 & 4.30 & 0.06 & 0.85 \\
\hline 7 & $\beta$-Aminoisobutyric acid & - & - & - & - & - & - & $>0.01$ & 7.59 \\
\hline 32 & Cystine & - & - & - & - & - & - & - & - \\
\hline 12 & Y-Aminobutyric acid & 0.26 & 6.43 & 0.32 & 5.32 & 0.38 & 4.03 & 0.22 & 0.33 \\
\hline 23 & Glutamic acid & 0.14 & 3.66 & 0.26 & 9.58 & 0.14 & 6.59 & 1.64 & 4.55 \\
\hline 2 & Glycine & 0.06 & 5.86 & 0.06 & 3.58 & 0.05 & 1.94 & 0.11 & 1.54 \\
\hline 28 & Histidine & 0.03 & 17.54 & 0.05 & 12.60 & 0.02 & 6.29 & 0.12 & 1.39 \\
\hline 33 & Homocystine & - & - & - & - & - & - & - & - \\
\hline 21 & Hydroxyproline & $>0.01$ & 11.58 & $>0.01$ & 7.49 & 0.01 & 10.52 & 0.01 & 3.20 \\
\hline 11 & Isoleucine & 0.05 & 8.06 & 0.04 & 9.32 & 0.02 & 5.81 & 0.04 & 4.26 \\
\hline 9 & Leucine & 0.01 & 0.24 & 0.01 & 6.85 & 0.02 & 6.61 & 0.06 & 4.21 \\
\hline 26 & Lysine & 0.01 & 2.37 & 0.02 & 5.77 & 0.01 & 2.76 & 0.24 & 1.05 \\
\hline 16 & Methionine & - & - & - & - & - & - & - & - \\
\hline 22 & 3-Methyl-L-histidine & 0.01 & 12.10 & 0.01 & 5.30 & 0.01 & 6.71 & 0.01 & 6.52 \\
\hline 25 & 1-Methyl-L-histidine & 0.02 & 0.51 & 0.02 & 3.84 & 0.02 & 2.77 & - & - \\
\hline 10 & Norleucine & 0.05 & 8.10 & 0.05 & 15.32 & 0.08 & 6.14 & 0.04 & 4.28 \\
\hline 24 & Ornithine & - & - & $>0.01$ & 41.42 & - & - & 0.02 & 8.07 \\
\hline 15 & Oxoproline & 0.04 & 0.93 & 0.03 & 17.36 & 0.03 & 8.96 & 0.02 & 2.76 \\
\hline 19 & Phenylalanine & 0.09 & 1.93 & 0.18 & 5.01 & 0.22 & 4.25 & 0.21 & 4.45 \\
\hline 14 & 2-Phenylglycine (I.S) & - & - & - & - & - & - & - & - \\
\hline 13 & Proline & 3.18 & 4.01 & 4.10 & 2.48 & 9.30 & 6.44 & 0.51 & 1.88 \\
\hline 3 & Sarcosine & - & - & - & - & - & - & - & - \\
\hline 17 & Serine & 0.05 & 0.28 & 0.06 & 4.09 & 0.03 & 4.98 & 0.18 & 3.15 \\
\hline 18 & Threonine & 0.02 & 3.49 & 0.02 & 4.89 & 0.03 & 5.82 & 0.14 & 3.21 \\
\hline 31 & Tryptophan & 0.07 & 25.49 & 0.08 & 8.60 & 0.04 & 1.09 & 0.13 & 4.01 \\
\hline 29 & Tyrosine & 0.02 & 6.68 & 0.04 & 2.05 & 0.03 & 8.74 & 0.02 & 8.59 \\
\hline 6 & Urea & - & - & - & - & - & - & - & - \\
\hline \multirow[t]{2}{*}{8} & Valine & 0.04 & 3.11 & 0.05 & 0.15 & 0.08 & 4.01 & 0.10 & 1.02 \\
\hline & SUM & 5.19 & & 6.58 & & 11.67 & & 11.71 & \\
\hline
\end{tabular}

the reference cigarettes is about the same, except for the $1 \mathrm{R} 5 \mathrm{~F}$ cigarette which has a slightly higher level of free amino acids. Individual amino acids levels also show some differences for the $1 \mathrm{R} 5 \mathrm{~F}$ cigarette, which has slightly higher levels of aspartic and glutamic acids.

Although the analysis of asparagine and glutamine using GC-MS quantitation after MTBSTFA derivatization is not directly possible, these two amino acids can be determined after hydrolysis. The extraction of tobacco with $2 \mathrm{~mL} 6 \mathrm{~N}$ $\mathrm{HCl}$ at room temperature for $1 \mathrm{~h}$ generates the results shown in Table 8 for samples of 2R4F tobacco. As seen from Table 8 , aspartic acid and glutamic acid levels are considerably higher when the extraction is done with $6 \mathrm{~N}$ $\mathrm{HCl}$, which allows the calculation of asparagine to be 3.1 $\mathrm{mg} / \mathrm{g}$ and of glutamine to be $0.82 \mathrm{mg} / \mathrm{g}$ in the $2 \mathrm{R} 4 \mathrm{~F}$ sample. The levels of the other amino acids are about the same for the two extraction conditions.

\section{The analysis of protein amino acids in tobacco}

The measurement of the amount of glutamine and asparagine in the tobacco protein is not possible when using a hydrolysis technique for the amino acid content evaluation. Under the conditions used, these amino acids undergo additional hydrolysis generating aspartic acid and glutamic acid. In addition, the analytical method for the free amino acid quantitation does not measure asparagine and glutamine. For these reasons, this study measured in fact hydrolyzable amino acid content including protein amino acids and a sum of aspartic acid and glutamic acid resulting from protein and from free asparagine and glutamine.

For digesting the tobacco proteins, a solution of $6 \mathrm{~N} \mathrm{HCl}$ with $1 \%$ phenol has been selected based on literature recommendations for protein hydrolysis in biological materials (21). The tobacco sample (optimization experiments were done only for $2 \mathrm{R} 4 \mathrm{~F}$ tobacco) was subjected to digestion at temperatures between $100{ }^{\circ} \mathrm{C}$ and $140{ }^{\circ} \mathrm{C}$ for periods of time between 1 and $4 \mathrm{~h}$. The results for alanine levels measured in the sample for different temperatures and three digestion times are given in Figure 9. The levels of other individual amino acids vary in a similar fashion, although with minor differences. The chromatograms for the total amino acids in a 2R4F sample hydrolyzed at $120{ }^{\circ} \mathrm{C}$ for $1 \mathrm{~h}$ (chromatogram A) and for $2 \mathrm{~h}$ (chromato- 
Table 7. Results in $\mathrm{mg} / \mathrm{g}$ of the analyzed free amino acids in the tobacco blend of several Kentucky reference cigarettes (three replicates except for $2 \mathrm{R} 4 \mathrm{~F}$ blend with five replicates

\begin{tabular}{|c|c|c|c|c|c|c|c|c|c|}
\hline \multirow[b]{2}{*}{ Peak no. } & \multirow[b]{2}{*}{ Compound } & \multicolumn{2}{|c|}{ 1R1 } & \multicolumn{2}{|c|}{ 1R3F } & \multicolumn{2}{|c|}{ 1R5F } & \multicolumn{2}{|c|}{$2 \mathrm{R} 4 \mathrm{~F}$} \\
\hline & & Average & $\mathrm{RSD} \%$ & Average & $\mathrm{RSD} \%$ & Average & $\mathrm{RSD} \%$ & Average & $\mathrm{RSD} \%$ \\
\hline 1 & $\alpha$-Alanine & 0.46 & 3.15 & 0.41 & 6.18 & 0.35 & 6.28 & 0.41 & 8.27 \\
\hline 27 & $\alpha$-Aminoadipic acid & $>0.01$ & 2.32 & $>0.01$ & 1.17 & - & - & $>0.01$ & 0.21 \\
\hline 4 & $\alpha$-Aminobutyric acid & - & - & - & - & - & - & - & - \\
\hline 30 & Arginine & 0.21 & 5.44 & 0.19 & 5.29 & 0.21 & 3.11 & 0.19 & 6.22 \\
\hline 20 & Aspartic acid & 1.69 & 2.67 & 2.22 & 3.24 & 3.08 & 6.56 & 2.46 & 6.11 \\
\hline 5 & $\beta$-Alanine & 0.04 & 12.47 & 0.03 & 7.40 & 0.05 & 8.36 & 0.02 & 12.49 \\
\hline 7 & $\beta$-Aminoisobutyric acid & - & - & - & - & - & - & - & - \\
\hline 32 & Cystine & - & - & - & - & 一 & 一 & - & - \\
\hline 12 & Y-Aminobutyric acid & 0.07 & 1.49 & 0.06 & 4.69 & 0.04 & 12.67 & 0.12 & 3.11 \\
\hline 23 & Glutamic acid & 0.44 & 0.66 & 0.66 & 6.18 & 1.58 & 7.69 & 0.75 & 2.12 \\
\hline 2 & Glycine & 0.09 & 3.52 & 0.08 & 5.65 & 0.11 & 9.02 & 0.08 & 10.17 \\
\hline 28 & Histidine & 0.27 & 0.92 & 0.13 & 0.64 & 0.09 & 3.12 & 0.13 & 3.05 \\
\hline 33 & Homocystine & - & - & - & - & - & - & - & - \\
\hline 21 & Hydroxyproline & 0.01 & 2.75 & 0.01 & 1.74 & 0.01 & 18.77 & 0.01 & 10.60 \\
\hline 11 & Isoleucine & 0.04 & 1.79 & 0.05 & 1.01 & 0.21 & 1.38 & 0.05 & 2.79 \\
\hline 9 & Leucine & 0.04 & 2.45 & 0.02 & 1.73 & 0.02 & 13.37 & 0.03 & 3.98 \\
\hline 26 & Lysine & 0.21 & 7.37 & 0.14 & 5.68 & 0.14 & 2.01 & 0.13 & 3.25 \\
\hline 16 & Methionine & - & - & - & - & - & - & - & - \\
\hline 22 & 3-Methyl-L-histidine & 0.01 & 12.38 & - & 21.60 & 0.01 & 16.25 & 0.01 & 8.17 \\
\hline 25 & 1-Methyl-L-histidine & 0.02 & 0.60 & 0.01 & 0.86 & 0.01 & 32.55 & 0.01 & 24.41 \\
\hline 10 & Norleucine & 0.01 & 1.67 & 0.03 & 0.93 & 0.08 & 1.28 & 0.03 & 1.76 \\
\hline 24 & Ornithine & $>0.01$ & 7.02 & $>0.01$ & 3.56 & $>0.01$ & 20.65 & 0.01 & 11.56 \\
\hline 15 & Oxoproline & 0.02 & 12.43 & 0.02 & 18.45 & 0.01 & 14.36 & 0.02 & 18.37 \\
\hline 19 & Phenylalanine & 0.45 & 0.15 & 0.27 & 0.15 & 0.20 & 6.73 & 0.24 & 4.70 \\
\hline 14 & 2-Phenylglycine (I.S) & - & - & - & - & - & - & - & - \\
\hline 13 & Proline & 3.91 & 0.02 & 3.74 & 0.14 & 3.03 & 5.91 & 3.44 & 2.48 \\
\hline 3 & Sarcosine & - & - & - & - & - & - & - & - \\
\hline 17 & Serine & 0.36 & 4.46 & 0.25 & 4.50 & 0.29 & 8.33 & 0.23 & 12.54 \\
\hline 18 & Threonine & 0.14 & 0.50 & 0.09 & 0.36 & 0.10 & 9.12 & 0.09 & 11.19 \\
\hline 31 & Tryptophan & 0.13 & 5.15 & 0.07 & 3.33 & 0.03 & 8.00 & 0.09 & 0.64 \\
\hline 29 & Tyrosine & 0.07 & 3.62 & 0.03 & 2.09 & 0.03 & 7.11 & 0.05 & 3.68 \\
\hline 6 & Urea & - & & - & & - & - & - & - \\
\hline \multirow[t]{2}{*}{8} & Valine & 0.18 & 5.93 & 0.09 & 4.30 & 0.10 & 11.49 & 0.09 & 6.11 \\
\hline & SUM & 8.87 & & 8.60 & & 9.78 & & 8.69 & \\
\hline
\end{tabular}

gram B) are given in Figure 10. Based on the overall results, it was decided to perform digestion for $2 \mathrm{~h}$ at $120{ }^{\circ} \mathrm{C}$. A slight increase in some amino acid content may be seen at longer hydrolysis times. However, this increase is less than $3-5 \%$, while some other amino acid levels, such as tryptophan show a slightly decreased concentration with longer digestion times.

The results for protein amino acids were generated by subtracting the average concentration for each free amino acid from the average of the total amino acid. The variability of the results was calculated assuming that all data were generated for three replicates (one sample for free amino acids in $2 \mathrm{R} 4 \mathrm{~F}$ blend was run in 5 replicates). The standard deviation $S_{\mathrm{d}}$ of each measurement is related to the standard error of the mean $S_{\mathrm{e}}$ by the well known formula $S_{\mathrm{e}}=S_{\mathrm{d}} /(n)^{1 / 2}$. The standard error of the mean of a difference is given by $S_{\mathrm{e}}=\left(S_{\mathrm{e} 1}^{2}+S_{\mathrm{e} 2}^{2}\right)^{1 / 2}$ where $S_{\mathrm{e} 1}$ and $S_{\mathrm{e} 2}$ are the standard errors of the two means which are subtracted. The standard deviations of the differences can be further calculated from the standard error of the mean. Because the number of measurements was assumed to always be the same, the $S_{\mathrm{d}}$ of the differences can be calculated directly. In this study, the $S_{\mathrm{d}}$ values were obtained from the formula $S_{\mathrm{d}}=\left(S_{\mathrm{d} 1}^{2}+S_{\mathrm{d} 2}^{2}\right)^{1 / 2}$ and subsequently the $\%$ RSD were obtained. Using the conditions previously described the results for the protein amino acids in five different flue-cured tobaccos, an Oriental, and a burley are given in Tables 9 and 10. Each sample was analyzed in triplicate and the results are expressed in $\mathrm{mg} / \mathrm{g}$ (amino acid/tobacco). The results for the protein amino acids (in $\mathrm{mg} / \mathrm{g}$ ) in four Kentucky reference cigarette blends are given in Table 11.

As seen from Table 9 and 10, the levels of amino acids in the proteins of different tobacco types do not follow the same pattern as those for free amino acids. Overall, the protein amino acids seem to show fewer differences compared to the free amino acids, which occur at quite different levels in different tobacco types. The levels of protein amino acids in the blend of the Kentucky reference cigarettes are also not very different. Some of the differences of individual levels, as well as the differences in the sums seen in Table 11 may be caused by the deviations from measurement to measurement. The sum of individual protein amino acids measured in the samples is 
Table 8. Comparison of the results $(\mathrm{mg} / \mathrm{g})$ of $2 \mathrm{R} 4 \mathrm{~F}$ tobacco sample extraction with $10 \mathrm{~mL} 0.1 \mathrm{NHCl}$, and with $2 \mathrm{~mL} 6 \mathrm{NHCl}$ for one hour

\begin{tabular}{|c|c|c|c|}
\hline $\begin{array}{l}\text { Peak } \\
\text { No. }\end{array}$ & Compound & $\begin{array}{c}\text { 2R4F regular } \\
\text { extraction }\end{array}$ & $\begin{array}{c}\text { 2R4F HCl } 6 \mathrm{~N} \\
\text { extraction }\end{array}$ \\
\hline 1 & $\alpha$-Alanine & 0.39 & 0.40 \\
\hline 27 & $\alpha$-Aminoadipic acid & - & - \\
\hline 4 & $\alpha$-Aminobutyric acid & - & - \\
\hline 30 & Arginine & 0.18 & 0.10 \\
\hline 20 & Aspartic acid & 2.39 & 5.51 \\
\hline 5 & $\beta$-Alanine & 0.02 & 0.03 \\
\hline 7 & $\beta$-Aminoisobutyric acid & - & - \\
\hline 32 & Cystine & - & - \\
\hline 12 & $\gamma$-Aminobutyric acid & 0.12 & 0.08 \\
\hline 23 & Glutamic acid & 0.73 & 1.55 \\
\hline 2 & Glycine & 0.08 & 0.12 \\
\hline 28 & Histidine & 0.13 & 0.13 \\
\hline 33 & Homocystine & - & - \\
\hline 21 & Hydroxyproline & 0.01 & 0.01 \\
\hline 11 & Isoleucine & 0.05 & 0.06 \\
\hline 9 & Leucine & 0.03 & 0.03 \\
\hline 26 & Lysine & 0.13 & 0.10 \\
\hline 16 & Methionine & - & - \\
\hline 22 & 3-Methyl-L-histidine & 0.01 & 0.02 \\
\hline 25 & 1-Methyl-L-histidine & 0.01 & 0.01 \\
\hline 10 & Norleucine & 0.03 & 0.04 \\
\hline 24 & Ornithine & 0.01 & 0.01 \\
\hline 15 & Oxoproline & 0.02 & 0.11 \\
\hline 19 & Phenylalanine & 0.23 & 0.26 \\
\hline 14 & 2-Phenylglycine (I.S) & - & - \\
\hline 13 & Proline & 3.34 & 3.14 \\
\hline 3 & Sarcosine & - & - \\
\hline 17 & Serine & 0.22 & 0.23 \\
\hline 18 & Threonine & 0.09 & 0.11 \\
\hline 31 & Tryptophan & 0.09 & 0.00 \\
\hline 29 & Tyrosine & 0.05 & 0.03 \\
\hline 6 & Urea & - & - \\
\hline \multirow[t]{2}{*}{8} & Valine & 0.09 & 0.10 \\
\hline & SUM & 8.24 & 12.19 \\
\hline
\end{tabular}

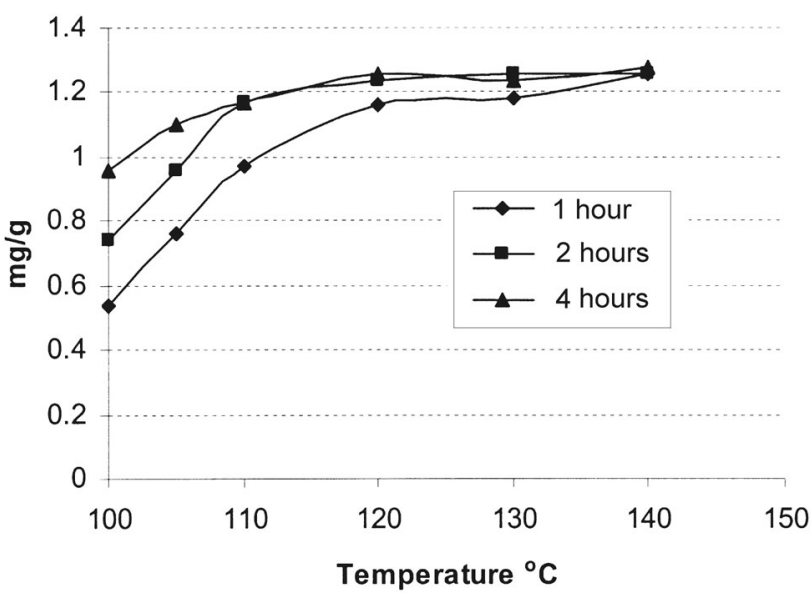

Figure 9. Results for total alanine level measured in a 2R4F sample for three different digestion times

in the range of reported levels for the protein content in tobacco (1). Also, the tobacco blends of the analyzed cigarettes show lower levels of protein amino acids than the unblended tobaccos probably due to the use of reconstituted tobaccos that are expected to have lower protein content.

\section{CONCLUSIONS}

A technique for the analysis of protein amino acids in tobacco has been developed. The technique is based on the measurement of free amino acids, of total amino acids obtained by digestion in $6 \mathrm{~N} \mathrm{HCl}$ for two hours in a microwave oven at $120^{\circ} \mathrm{C}$ in sealed vials, and by the subtraction of the two values. The amino acids in solution were measured using a GC-MS procedure. The technique described in this study provides reliable results with less
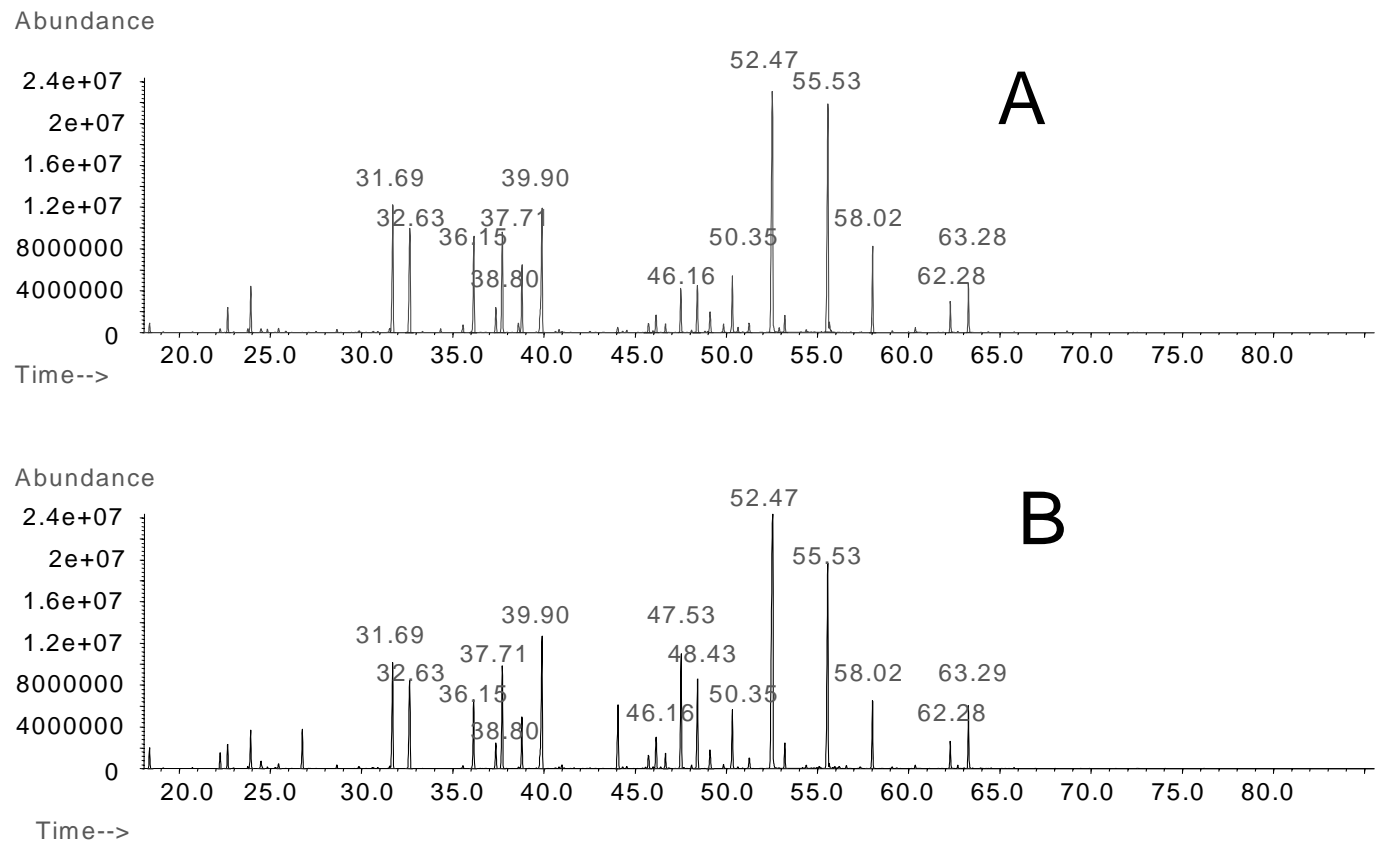

Figure 10. Chromatograms for the total amino acids in a $2 \mathrm{R} 4 \mathrm{~F}$ sample hydrolyzed at $120^{\circ} \mathrm{C}$ for $1 \mathrm{~h}$ (chromatogram $\mathrm{A}$ ) and for $2 \mathrm{~h}$ (chromatogram B) 
Table 9. Protein amino acid content in four different flue-cured tobaccos

\begin{tabular}{|c|c|c|c|c|c|c|c|c|c|}
\hline \multirow[b]{2}{*}{ Peak no. } & \multirow[b]{2}{*}{ Compound } & \multicolumn{2}{|c|}{ Flue-cured 1} & \multicolumn{2}{|c|}{ Flue-cured 2} & \multicolumn{2}{|c|}{ Flue-cured 3} & \multicolumn{2}{|c|}{ Flue-cured 4} \\
\hline & & Average & $\mathrm{RSD} \%$ & Average & RSD\% & Average & $\mathrm{RSD} \%$ & Average & $\mathrm{RSD} \%$ \\
\hline 1 & $\alpha$-alanine & 0.95 & 2.14 & 1.16 & 9.11 & 0.69 & 2.45 & 0.99 & 4.36 \\
\hline 27 & $\alpha$-Aminoadipic acid & $>0.01$ & 17.99 & $>0.01$ & 5.77 & $>0.01$ & 7.49 & $>0.01$ & 10.12 \\
\hline 4 & $\alpha$-Aminobutyric acid & 0.00 & 2.75 & - & 7.05 & $>0.01$ & 0.31 & $>0.01$ & 3.06 \\
\hline 30 & Arginine & 0.34 & 0.20 & 0.16 & 2.22 & 0.42 & 3.34 & 0.23 & 2.06 \\
\hline 20 & Aspartic acid & 9.53 & 1.07 & 5.98 & 8.50 & 3.65 & 3.65 & 3.23 & 4.33 \\
\hline 5 & $\beta$-Alanine & 0.01 & 6.01 & 0.02 & 4.06 & 0.01 & 4.00 & 0.02 & 4.62 \\
\hline 7 & $\beta$-Aminoisobutyric acid & - & - & - & - & $>0.01$ & 1.93 & - & - \\
\hline 32 & Cystine & $>0.01$ & 5.94 & $>0.01$ & 5.28 & $>0.01$ & 9.40 & $>0.01$ & 7.13 \\
\hline 12 & Y-Aminobutyric acid & 0.19 & 5.88 & 0.18 & 11.08 & 0.17 & 8.76 & 0.09 & 8.59 \\
\hline 23 & Glutamic acid & 5.39 & 7.75 & 5.44 & 2.00 & 4.76 & 1.34 & 3.78 & 3.46 \\
\hline 2 & Glycine & 1.65 & 9.55 & 1.55 & 8.61 & 1.53 & 9.59 & 1.28 & 9.28 \\
\hline 28 & Histidine & 0.28 & 8.34 & 0.48 & 5.64 & 0.30 & 0.67 & 0.37 & 4.46 \\
\hline 33 & Homocystine & - & - & - & - & - & - & - & - \\
\hline 21 & Hydroxyproline & 0.36 & 5.35 & 0.29 & 1.52 & $>0.01$ & 7.87 & 0.32 & 5.21 \\
\hline 11 & Isoleucine & 0.86 & 4.82 & 0.91 & 1.33 & 0.52 & 8.00 & 0.54 & 5.05 \\
\hline 9 & Leucine & 1.93 & 7.99 & 1.81 & 11.97 & 1.93 & 10.16 & 1.34 & 10.05 \\
\hline 26 & Lysine & 1.59 & 7.82 & 1.48 & 2.86 & 1.17 & 4.33 & 1.10 & 4.94 \\
\hline 16 & Methionine & - & - & $>0.01$ & 4.30 & $>0.01$ & 6.65 & - & - \\
\hline 22 & 3-Methyl-L-histidine & $>0.01$ & 5.82 & $>0.01$ & 2.34 & 0.01 & 6.28 & 0.00 & 4.96 \\
\hline 25 & 1-Methyl-L-histidine & 0.02 & 6.14 & 0.02 & 16.46 & 0.04 & 14.42 & 0.02 & 12.55 \\
\hline 10 & Norleucine & 0.87 & 4.85 & 0.87 & 8.30 & 0.48 & 7.95 & 0.14 & 7.13 \\
\hline 24 & Ornithine & 0.03 & 7.43 & 0.03 & 5.85 & $>0.01$ & 2.44 & $>0.01$ & 4.96 \\
\hline 15 & Oxoproline & 0.55 & 21.39 & 0.38 & 19.28 & 0.58 & 19.05 & 0.29 & 19.82 \\
\hline 19 & Ohenylalanine & 0.95 & 5.34 & 1.01 & 1.99 & 0.82 & 6.86 & 0.79 & 4.94 \\
\hline 14 & Phenylglycine (I.S) & - & - & - & - & - & - & - & - \\
\hline 13 & Proline & 3.06 & 1.82 & 4.72 & 4.18 & 1.18 & 1.22 & 4.08 & 2.29 \\
\hline 3 & Sarcosine & - & - & - & - & - & - & - & - \\
\hline 17 & Serine & 1.24 & 8.54 & 1.17 & 7.76 & 1.22 & 1.50 & 1.10 & 5.49 \\
\hline 18 & Threonine & 1.08 & 5.29 & 1.06 & 3.49 & 1.14 & 1.56 & 0.85 & 3.26 \\
\hline 31 & Tryptophan & 0.60 & 1.42 & 0.54 & 2.34 & 0.32 & 4.25 & 0.07 & 2.83 \\
\hline 29 & Tyrosine & 0.85 & 3.55 & 0.82 & 10.78 & 0.73 & 6.15 & 0.60 & 6.76 \\
\hline 6 & Urea & - & - & - & - & - & - & - & - \\
\hline \multirow[t]{2}{*}{8} & Valine & 1.09 & 7.91 & 1.08 & 7.56 & 1.09 & 8.00 & 0.68 & 7.84 \\
\hline & SUM & 28.44 & & 29.15 & & 21.77 & & 22.31 & \\
\hline
\end{tabular}

than $10 \%$ RSD for most amino acids. Only the determination of very low level amino acids is affected by larger errors. The levels of amino acids in the proteins of different tobacco types do not follow the same pattern as those for free amino acids. Overall, the protein amino acids seem to show fewer differences compared to the free amino acids, which occur at quite different levels in different tobacco types. The levels of protein amino acids in the blend of the Kentucky reference cigarettes are not very different. The sum of individual protein amino acids measured in the samples is in the range of reported levels for protein content in tobacco.

\section{REFERENCES}

1. Weeks, W.W.: Relationship between leaf chemistry and organoleptic properties of tobacco smoke; in: Tobacco: Production, chemistry and technology, edited by D.L. Davis and M.T. Nielsen, Blackwell Science, Oxford, 1999, pp. 304-312.

2. Moldoveanu, S.C. and V. David: Sample preparation in chromatography; Elsevier, Amsterdam, 2002, pp.
789-814.

3. Lunn, G. and L.C. Hellwig: Handbook of derivatization reactions for HPLC; John Wiley, New York, 1998, pp. 625-819.

4. de la Burde, R., E.H. Poindexter Jr., and J.P. Bell: The distribution of amino acids in tobaccos from different stalk regions; Tob. Sci. 9 (1965) 26-32.

5. Noguchi, M., K. Yamamoto, and E. Tamaki: Studies on nitrogen metabolism in tobacco plants. A. Part V. Changes in the free amino acid composition of tobacco leaves with age; Tob. Sci. 8 (1964) 8-12.

6. Tso, T.C. and M.E. Engelhaupt: Amino acid content to gradual development of calcium and boron deficiency symptoms in tobacco plant; Tob. Sci. 7 (1963) 12-16.

7. Li, P., M. Wu, and J. Xie: Changes in levels of amino acids and basic components in burley tobacco produced by roasting; Beitr. Tabakforsch. Int. 20 (2003) 459-466.

8. Petridis, K., C. Elfakir, and M. Dreux: HPLC-CLND for the analysis of underivatized amino acids; LC-GC Europe 14 (2001) 389-390.

9. Petridis, K., C. Elfakir, and M. Dreux: HPLC-CLND for the analysis of underivatized amino acids; LC-GC 
Table 10. Protein amino acid content in a flue-cured tobacco, an Oriental, and a burley

\begin{tabular}{|c|c|c|c|c|c|c|c|}
\hline \multirow[b]{2}{*}{ Peak no. } & \multirow[b]{2}{*}{ Compound } & \multicolumn{2}{|c|}{ Flue-cured 5} & \multicolumn{2}{|c|}{ Oriental } & \multicolumn{2}{|c|}{ Burley } \\
\hline & & Average & $\mathrm{RSD} \%$ & Average & $\mathrm{RSD} \%$ & Average & $\mathrm{RSD} \%$ \\
\hline 1 & $\alpha$-Alanine & 1.17 & 3.38 & 1.31 & 2.89 & 1.79 & 1.76 \\
\hline 27 & $\alpha$-Aminoadipic acid & $>0.01$ & 11.65 & $>0.01$ & 6.99 & 0.04 & 6.86 \\
\hline 4 & $\alpha$-Aminobutyric acid & $>0.01$ & 2.85 & $>0.01$ & 5.54 & $>0.01$ & 6.72 \\
\hline 30 & Arginine & 0.21 & 1.21 & 0.09 & 0.91 & 0.14 & 0.59 \\
\hline 20 & Aspartic acid & 3.80 & 2.97 & 2.90 & 3.83 & 2.06 & 2.53 \\
\hline 5 & $\beta$-Alanine & 0.02 & 4.62 & $>0.01$ & 2.55 & 0.02 & 1.63 \\
\hline 7 & $\beta$-Aminoisobutyric acid & - & - & - & - & - & - \\
\hline 32 & Cystine & $>0.01$ & 5.91 & $>0.01$ & 6.55 & $>0.01$ & 7.92 \\
\hline 12 & Y-Aminobutyric acid & 0.09 & 6.91 & 0.04 & 12.24 & 0.07 & 13.97 \\
\hline 23 & Glutamic acid & 4.89 & 4.54 & 5.46 & 1.10 & 4.26 & 0.38 \\
\hline 2 & Glycine & 1.46 & 8.42 & 1.57 & 10.86 & 2.30 & 3.36 \\
\hline 28 & Histidine & 0.37 & 5.43 & 0.44 & 1.29 & 0.74 & 0.67 \\
\hline 33 & Homocystine & - & - & - & - & - & - \\
\hline 21 & Hydroxyproline & 0.22 & 4.55 & 0.12 & 1.97 & 0.39 & 2.01 \\
\hline 11 & Isoleucine & 0.46 & 4.28 & 1.13 & 1.76 & 0.99 & 1.82 \\
\hline 9 & Leucine & 1.37 & 8.42 & 2.14 & 15.39 & 2.29 & 19.96 \\
\hline 26 & Lysine & 0.93 & 5.35 & 1.46 & 2.27 & 2.02 & 1.46 \\
\hline 16 & Methionine & - & - & - & - & - & - \\
\hline 22 & 3-Methyl-L-histidine & 0.00 & 4.63 & 0.00 & 2.35 & 0.00 & 2.00 \\
\hline 25 & 1-Methyl-L-histidine & 0.02 & 9.25 & $>0.01$ & 29.10 & $>0.01$ & 51.99 \\
\hline 10 & Norleucine & 0.15 & 5.68 & 0.07 & 8.40 & 0.19 & 8.85 \\
\hline 24 & Ornithine & 0.03 & 5.37 & $>0.01$ & 2.46 & 0.07 & 1.30 \\
\hline 15 & Oxoproline & 0.41 & 18.36 & 0.30 & 46.21 & 0.33 & 17.57 \\
\hline 19 & Phenylalanine & 0.79 & 4.44 & 1.14 & 2.17 & 1.40 & 1.99 \\
\hline 14 & 2-Phenylglycine (I.S) & - & - & - & - & - & - \\
\hline 13 & Proline & 4.49 & 1.99 & 4.38 & 0.79 & 4.15 & 0.53 \\
\hline 3 & Sarcosine & - & - & - & - & - & - \\
\hline 17 & Serine & 1.16 & 6.12 & 1.17 & 2.25 & 1.78 & 1.18 \\
\hline 18 & Threonine & 0.81 & 3.66 & 1.24 & 1.18 & 1.57 & 0.57 \\
\hline 31 & Tryptophan & 0.08 & 2.03 & 0.00 & 1.34 & 0.13 & 0.92 \\
\hline 29 & Tyrosine & 0.60 & 5.16 & 0.79 & 8.31 & 1.12 & 7.21 \\
\hline 6 & Urea & - & - & - & - & - & - \\
\hline \multirow[t]{2}{*}{8} & Valine & 0.61 & 7.07 & 1.40 & 8.05 & 1.20 & 8.48 \\
\hline & SUM & 24.42 & & 28.13 & & 27.84 & \\
\hline
\end{tabular}

Europe 14 (2001) 392-395.

10. Wathelet, B.: Nutritional analysis for proteins and amino acids in beans (Phaseolus sp.); Biotechnol. Agron. Soc. Environ. 3 (1999) 197-200.

11. Xie, F.W.: OPA (o-phenyldialdehyde) auto precolumn derivatization reverse phase high performance liquid chromatography; $3^{\text {rd }}$ National Member's Congress of China Tobacco Society, 1996, pp. 208-218.

12. Cohen, S.A. and D.P. Michaud: Synthesis of a fluorescent reagent, 6-aminoquinolyl- $N$-hydrazosuccinimidyl carbamate, and its application for the analysis of hydrolysate amino acids with high performance liquid chromatography; Anal. Biochem. 211 (1993) 279-287.

13. Cohen, S.A., M. Meys, and T.L. Tarvin: The pico tag method, a manual of advanced techniques for amino acid analysis; Waters, Milford, MA 01757, 2003.

14. Burch, T.H., J.H. Lauterbach, and S.C. Moldoveanu: Comparative study of several methods for the determination of free amino acids in tobacco; $44^{\text {th }}$ Tobacco Chem. Res. Conf., Program Booklet and Abstracts No. 15, p. 18, Winston-Salem, 1990.

15. Mawhinney, T.P., R.S.R. Robinett, A. Atalay, and M.A. Madson: Analysis of amino acids as their $t$-butyldimethylsilyl derivatives by gas-liquid chromatography and mass spectrometry; J. Chromatogr. 358 (1986) 231-242.

16. Husek, P., Quantitation of amino acids as chloroformates - A return to gas chromatography; in: Quantitation of amino acids and amines by chromatography, edited by I. Molnar-Perl, Elsevier, Amsterdam, 2005, pp. 2-38.

17. Makita, M., S. Yamamoto, and M. Kono: Gas-liquid chromatographic analysis of protein amino acids as $\mathrm{N}$ isobutyloxycarbonylamino acid methyl esters; J. Chromatogr. 120 (1976) 129-140.

18. Makita, M., S., Yamamoto, K. Sakai, and M. Shiraishi: Gas-liquid chromatography of the $N$-isobutyloxycarbonyl methyl esters of non-protein amino acids; J. Chromatogr. 124 (1976) 92-96.

19. Jellum, E., V.A. Close, W. Patton, W. Pereira, and B. Halpern: A gas-liquid chromatographic method for the determination of phenylalanine in serum; Anal. Biochem. 31 (1969) 227-234.

20. Leffingwell, J.C.: Nitrogen component of leaf and their relationship to smoking quality and aroma; Rec. Adv. Tob. Sci. Vol. 2 (1976) 1-31.

21. Ward, L.D., G.E. Reid, R.L. Moritz, and R.J. Simpson: Strategies for internal amino acid sequence analysis of proteins separated by polyacrylamide gel electrophoresis; J. Chromatogr. 519 (1990) 199-216. 
Table 11. Protein amino acid content in four Kentucky reference cigarette blends

\begin{tabular}{|c|c|c|c|c|c|c|c|c|c|}
\hline \multirow[b]{2}{*}{ Peak no. } & \multirow[b]{2}{*}{ Compound } & \multicolumn{2}{|c|}{ 1R1 } & \multicolumn{2}{|c|}{ 1R3F } & \multicolumn{2}{|c|}{ 1R5F } & \multicolumn{2}{|c|}{$2 \mathrm{R} 4 \mathrm{~F}$} \\
\hline & & Average & RSD \% & Average & $\mathrm{RSD} \%$ & Average & $\mathrm{RSD} \%$ & Average & $\mathrm{RSD} \%$ \\
\hline 1 & $\alpha$-Alanine & 1.13 & 9.63 & 0.84 & 8.35 & 0.86 & 2.11 & 0.86 & 1.43 \\
\hline 27 & $\alpha$-Aminoadipic acid & $>0.01$ & 6.22 & $>0.01$ & 9.09 & $>0.01$ & 9.89 & $>0.01$ & 6.94 \\
\hline 4 & $\alpha$-Aminobutyric acid & $>0.01$ & 6.87 & $>0.01$ & 7.11 & $>0.01$ & 1.01 & - & - \\
\hline 30 & Arginine & 0.21 & 3.20 & 0.19 & 1.39 & 0.21 & 2.06 & 0.19 & 4.33 \\
\hline 20 & Aspartic acid & 3.74 & 9.49 & 4.07 & 7.24 & 4.82 & 2.51 & 4.10 & 2.61 \\
\hline 5 & $\beta$-Alanine & 0.00 & 4.66 & 0.01 & 4.66 & 0.01 & 4.20 & 0.01 & 12.06 \\
\hline 7 & $\beta$-Aminoisobutyric acid & - & - & - & - & - & - & - & - \\
\hline 32 & Cystine & $>0.01$ & 7.51 & $>0.01$ & 4.65 & $>0.01$ & 7.42 & $>0.01$ & 28.72 \\
\hline 12 & Y-Aminobutyric acid & 0.12 & 13.12 & 0.05 & 9.98 & 0.06 & 7.02 & 0.06 & 3.23 \\
\hline 23 & Glutamic acid & 4.54 & 1.63 & 4.36 & 3.86 & 4.87 & 3.13 & 4.34 & 1.14 \\
\hline 2 & Glycine & 1.36 & 10.53 & 1.04 & 8.70 & 1.14 & 8.62 & 1.36 & 1.33 \\
\hline 28 & Histidine & 0.32 & 5.01 & 0.12 & 7.44 & 0.22 & 2.90 & 0.23 & 7.58 \\
\hline 33 & Homocystine & - & - & - & - & - & - & - & - \\
\hline 21 & Hydroxyproline & 0.18 & 3.35 & 0.07 & 1.40 & 0.10 & 6.33 & 0.31 & 6.49 \\
\hline 11 & Isoleucine & 0.82 & 3.25 & 0.15 & 1.04 & 0.16 & 6.25 & 0.60 & 7.78 \\
\hline 9 & Leucine & 1.59 & 14.22 & 1.63 & 11.14 & 1.01 & 8.49 & 1.49 & 6.56 \\
\hline 26 & Lysine & 1.05 & 3.38 & 0.81 & 4.05 & 0.47 & 4.94 & 0.89 & 5.93 \\
\hline 16 & Methionine & - & - & $>0.01$ & 5.13 & - & - & $>0.01$ & 1.13 \\
\hline 22 & 3-Methyl-L-histidine & $>0.01$ & 3.64 & $>0.01$ & 2.60 & 0.00 & 5.51 & 0.01 & 4.37 \\
\hline 25 & 1-Methyl-L-histidine & 0.02 & 20.17 & 0.01 & 13.77 & 0.01 & 10.49 & 0.02 & 5.64 \\
\hline 10 & Norleucine & 0.85 & 10.20 & 0.57 & 7.34 & 0.29 & 6.23 & 0.63 & 7.85 \\
\hline 24 & Ornithine & $>0.01$ & 5.84 & $>0.01$ & 7.01 & $>0.01$ & 3.69 & 0.03 & 6.12 \\
\hline 15 & Oxoproline & 0.59 & 22.86 & 0.69 & 19.96 & 0.49 & 17.85 & 0.66 & 9.27 \\
\hline 19 & Phenylalanine & 0.74 & 3.51 & 0.55 & 2.02 & 0.54 & 5.72 & 0.58 & 5.64 \\
\hline 14 & 2-Phenylglycine (I.S) & - & - & - & - & - & - & - & \\
\hline 13 & Proline & 1.53 & 4.36 & 1.33 & 4.06 & 1.16 & 1.28 & 1.11 & 4.99 \\
\hline 3 & Sarcosine & - & - & - & - & - & - & - & - \\
\hline 17 & Serine & 0.82 & 7.36 & 0.95 & 9.25 & 0.72 & 3.46 & 0.88 & 8.51 \\
\hline 18 & Threonine & 0.92 & 3.43 & 0.83 & 4.42 & 0.59 & 2.52 & 0.88 & 7.80 \\
\hline 31 & Tryptophan & 0.13 & 3.47 & 0.17 & 1.68 & 0.03 & 2.98 & 0.18 & 3.28 \\
\hline 29 & Tyrosine & 0.67 & 12.27 & 0.49 & 9.54 & 0.48 & 4.76 & 0.61 & 4.64 \\
\hline 6 & Urea & - & - & - & - & - & - & - & - \\
\hline \multirow[t]{2}{*}{8} & Valine & 0.91 & 9.17 & 0.59 & 7.58 & 0.40 & 7.17 & 0.69 & 5.32 \\
\hline & SUM & 22.25 & & 19.52 & & 18.66 & & 20.72 & \\
\hline
\end{tabular}

22. West, K.A. and J.W. Crabb: Performance evaluation of automatic hydrolysis and PTC amino acid analysis; in: Current research in protein chemistry, edited by J.J. Villafranca, Academic Press, 1990, pp. 37-48.

23. Crabb, J.W., L. Ericsson, D. Atherton, A.J. Smith, and R. Kunty: A collaborative amino acid analysis study from the Association of Biomolecular Resource Facilities; in: Current research in protein chemistry, edited by J.J. Villafranca, Academic Press, 1990, pp. 49-61.

24. Strydom, D.J., T.T. Andersen, I. Apostol, J.W. Fox, R.J. Paxton, and J.W. Crabb: Cysteine and tryptophan amino acid analysis of ABRF92-AAA; in: Techniques in protein chemistry IV, edited by R.H. Angeletti, Academic Press, 1993, pp. 279-288.

25. Tarr, G.E., R.J. Paxton, Y.E. Pan, L.H. Ericsson, and J.W. Crabb: Amino acid analysis 1990: The third collaborative study from the Association of Biomolecular Resource Facilities; in: Current research in protein chemistry, edited by J.J. Villafranca, Academic Press, 1990, 139-149.

26. Chiou, S.H. and K.T. Wang: Peptide and protein hydrolysis by microwave irradiation; J. Chromatogr. 491 (1989) 424-431.

27. Chen, P.X., N. Qian, H.R. Burton, and S.C. Moldoveanu: Analysis of minor alkaloids in tobacco: a collaborative study; Beitr. Tabakforsch. Int. 21 (2005) 369-379.

28. Byrd, C.H. and L.M. Dominguez: R.J. Reynolds Tobacco Co., personal communication.

29. Haynes, P.A., D. Sheumack, L.G. Grieg, J. Libby, and J.W. Redmond: Applications of automated amino acid analysis using 9-fluorenylmethyl chloroformate; J. Chromatogr. 588 (1991) 107-114.

30. Dominguez, L.M., C.H. Byrd, and J.W. Marshall: Free amino acids and nicotine in burley tobaccos; 56th Tobacco Science Research Conference, Program Booklet and Abstracts No. 21, p. 30, Lexington, KY, 2002.

Address for correspondence:

Serban C. Moldoveanu

R.J. Reynolds Tobacco Co. 950 Reynolds Boulevard

Winston-Salem, NC 27105

USA

E-mail:smoldov@rjrt.com 